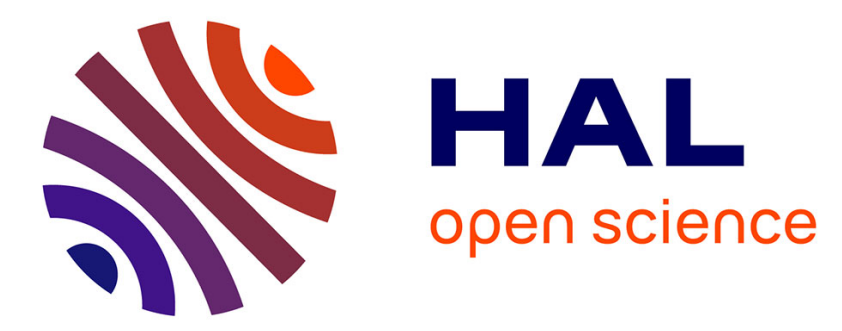

\title{
Impact of mafic underplating and mantle depletion on subsequent rifting: a numerical modeling study
}

Pauline Chenin, Suzon Jammes, Luc L Lavier, Gianreto Manatschal, Suzanne

Picazo, Othmar Müntener, Garry D. Karner, Patricio H Figueredo, Christopher Johnson

\section{To cite this version:}

Pauline Chenin, Suzon Jammes, Luc L Lavier, Gianreto Manatschal, Suzanne Picazo, et al.. Impact of mafic underplating and mantle depletion on subsequent rifting: a numerical modeling study. Tectonics, 2019, 10.1029/2018TC005318 . hal-02178691

\section{HAL Id: hal-02178691 \\ https://hal.science/hal-02178691}

Submitted on 10 Jul 2019

HAL is a multi-disciplinary open access archive for the deposit and dissemination of scientific research documents, whether they are published or not. The documents may come from teaching and research institutions in France or abroad, or from public or private research centers.
L'archive ouverte pluridisciplinaire HAL, est destinée au dépôt et à la diffusion de documents scientifiques de niveau recherche, publiés ou non, émanant des établissements d'enseignement et de recherche français ou étrangers, des laboratoires publics ou privés. 


\title{
Impact of mafic underplating and mantle depletion on subsequent rifting: a numerical modeling study
}

Pauline Chenin ${ }^{1 *}$, Suzon Jammes ${ }^{2}$, Luc L. Lavier ${ }^{3}$, Gianreto Manatschal ${ }^{1}$, Suzanne Picazo ${ }^{4}$, Othmar Müntener ${ }^{4}$, Garry D. Karner ${ }^{5}$, Patricio H. Figueredo $^{5}$ and Christopher Johnson ${ }^{5}$

* Corresponding author: Pauline Chenin pauline.chenin@fulbrightmail.org

${ }^{1}$ Centre National de la Recherche Scientifique - Institut de Physique du Globe de Strasbourg - Université de Strasbourg ${ }^{2}$ Department of Geography, Texas State University ${ }^{3}$ UTIG - Department of Geological Sciences - University of Texas at Austin ${ }^{4}$ Université de Lausanne, Institut des Sciences de la Terre ${ }^{5}$ ExxonMobil Exploration Company, Subsurface Characterization, Global Tectonics \& Structure

${ }^{1} 1$ rue Blessig, 67084 Strasbourg, France ${ }^{2} 601$ University Dr, San Marcos, TX 78666, USA ${ }^{3} 10601$ Exploration Way, Austin, TX $78758{ }^{4}$ Bâtiment Géopolis CH-1015

Lausanne, Switzerland ${ }^{5}$ ExxonMobil Houston Campus, 22777 Springwoods Village Pkwy, Spring, TX 77389, USA

\section{Keypoints}

- Mafic underplating of the crust generally prevents rifting of overlying weaknesses

- The North Atlantic and Alpine Tethys rifts avoided the underplated Variscan domain in W-Europe

\begin{abstract}
Orogenesis in the Variscan belt of Western Europe was followed by a major magmatic event during the Permian that formed a mafic lower crust by crystallising pyroxenite and gabbros from mantle-derived melts at the base of the continental crust. Partial melting of the asthenosphere left a significantly depleted mantle that was progressively incorporated into the subcontinental lithospheric mantle as the orogenic domain cooled. The potential impact of such large-scale thermal and lithologic layering has never been taken into account in the study of the Alpine Tethys and North Atlantic rift systems that developed subsequently in Western Europe. Here we investigate via numerical modeling how a mafic heterogeneity within the lowermost part of a quartzo-feldspathic
\end{abstract}


continental crust and/or a zone of depleted mantle within the lithospheric mantle beneath a former orogenic domain could have influenced subsequent rifting. Our numerical modeling results indicate that, in a thermally equilibrated lithosphere, a mafic body within the lower continental crust or a zone of shallow depleted mantle prevents rifting of overlying weaknesses (e.g. faults, suture zones). We propose that the regional mafic lower crust beneath the Variscan orogenic domain may explain why the Tethyan and southern North-Atlantic rift systems did not localize at former suture zones of the Western European orogenic lithosphere.

\section{Introduction}

When studying rifting, numerical modelers usually assume that the lithosphere is comprised of layers with horizontally homogeneous physical properties (e.g. Lavier and Manatschal, 2006; Huismans and Beaumont, 2011; Brune et al., 2014). However, orogenic processes are characterized by pervasive and long-lasting structural and compositional heterogeneities such as suture zones, faults/shear zones and magmatic additions in both the crust and the subcontinental lithospheric mantle (e.g. Manatschal et al., 2015). Inherited heterogeneities may represent zones of either increased strength or weaknesses. For instance, faults may be more prone to deformation compared to unaltered/undeformed surrounding material (e.g. Holdsworth et al., 1997). Suture zones are largely comprised of weak, hydrated materials (e.g. serpentinite, hyaloclastites, sediments; see Hall (1976); Haynes and McQuillan (1974)). Mafic intrusions may represent a thermally weakened region in the early stages of their emplacement but become strong heterogeneities once they have cooled (Krabbendam, 2001).

Because rift location tends to take advantage of inherited weaknesses (e.g. Sykes, 1978; Dunbar and Sawyer, 1989), rifts usually localize along former orogenic belts (Wilson, 1966; Audet and Bürgmann, 2011), as is the case for the northern North Atlantic, where extension tends to follow the sutures or fold-and-thrust belts of the Caledonian orogen of Norway-Greenland (Wilson (1966); Figure 1a). However, the Alpine Tethys and southern North Atlantic rift systems are striking counterexamples where both avoided the core of the Variscan orogen to the southeast and to the west, respectively (Figure 1b; Chenin et al. (2015); Frizon de Lamotte et al. (2011)). 
One major characteristic feature of the Western European lithosphere is the existence of widespread magmatic intrusions and underplating of the continental crust (Figures 1c and d; Bois et al. (1989); Rey (1993); Schuster and Stüwe (2008)), which occurred during late stages and after the orogenic collapse of the Variscan orogen (Petri et al., 2017). In contrast, the continental margins of Norway and Greenland do not show evidence for pre-rift underplating, and no significant post-orogenic magmatic activity is recorded north of the Elbe lineament during Permian times (Figure 1c; Meissner, 1999; Fossen et al., 2014).

The effects of a continuous strong lower crust have largely been investigated with numerical models (e.g. Huismans and Beaumont, 2007; Nagel and Buck, 2007; Huismans and Beaumont, 2011), including the impact of multiple continuous strong layers within both the upper and lower crust (Duretz et al., 2016). However, the impact of a discontinuous strong lower crust or locally strong heterogeneities has been largely overlooked in numerical models. An exception is the recent study by Petri et al. (2019), where the authors investigate the behavior of a heterogeneous lithosphere comprising both regions of increased and decreased rheological strength during extension. This study indicates that strong heterogeneities tend to remain little deformed during extension as they are laterally extracted from the rift center along high-strain shear zones that form within the encompassing weaker material. An analog modeling study was undertaken by Cappelletti et al. (2013) to investigate the effect of local/discontinuous lithospheric strong heterogeneities. Their experiments show that deformation tends to avoid and bypass strong lower crustal bodies and that both upper crust and mantle deformation tend to focus at the edges of such strong bodies.

In this study, we investigate with numerical modeling how magmatic underplating of the continental crust and associated mantle depletion may impact the style of subsequent extensional events. We design numerical models to compare the evolution of orogenic lithospheres with various distributions of crustal underplate and mantle depletion using different geothermal gradients. We discuss the results in light of the Alpine Tethys and North-Atlantic rift systems, whose pre-rift orogenic lithospheres and rifting histories have been extensively studied. 

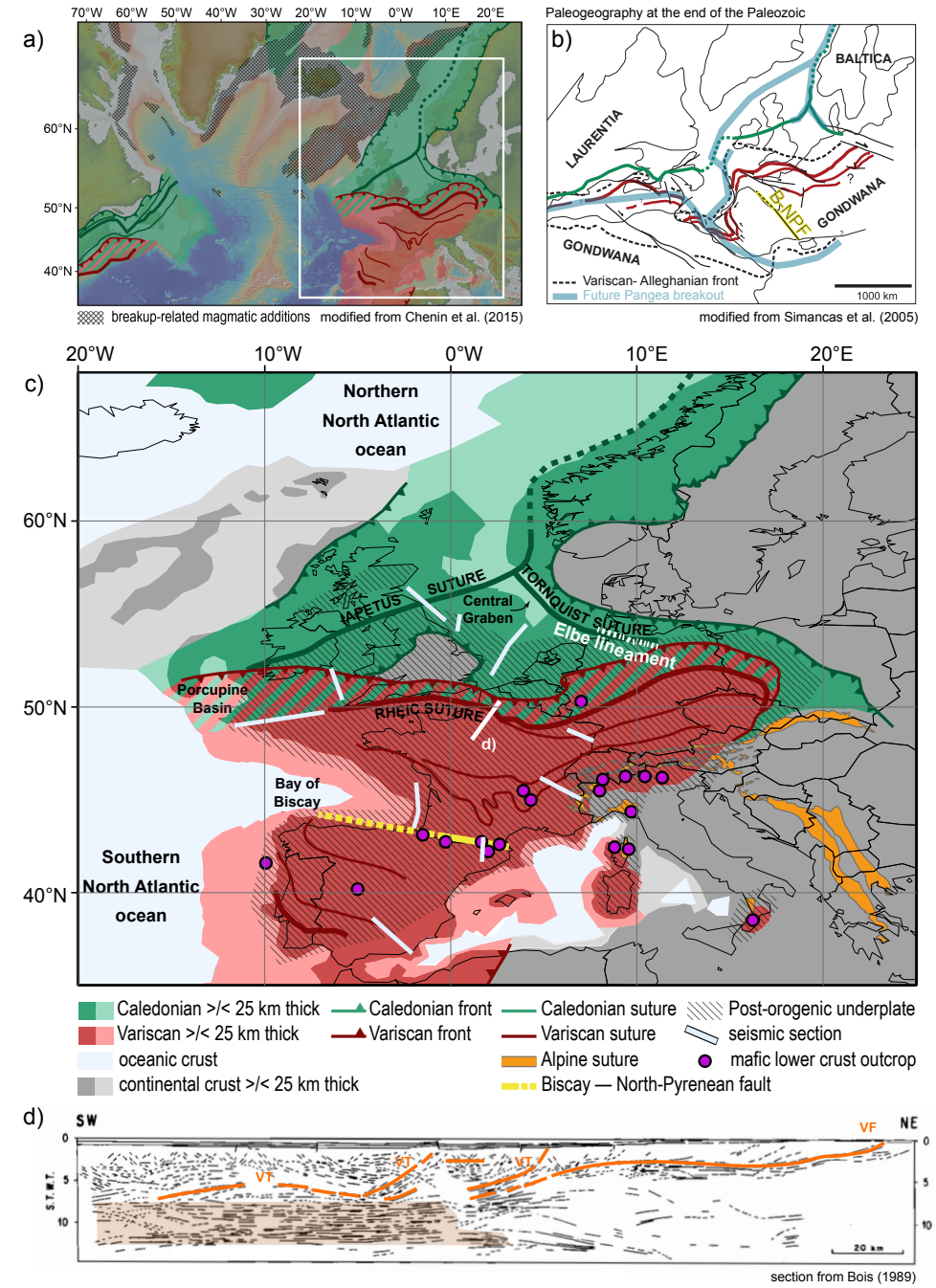

Figure 1: a) Extent of the Caledonian and Variscan orogenic domains and location of breakup-related magmatic additions in the North Atlantic region (Chenin et al. (2015); background map from Haxby et al. (2010)). b) Paleogeographic restoration of Western Europe during the late Paleozoic (modified from Simancas et al., 2005) showing the location of the Caledonian (green) and Variscan (red) sutures, as well as the location of the future Pangea breakout; BNPF: Biscay-North Pyrenean fault from Arthaud and Matte (1977). c) Major orogenic structures in Western Europe; the green and red striped region records both the Caledonian and Variscan orogenies; sutures and deformation fronts are from Ziegler and Dèzes (2006); the hatched area represents the rough extent of post-orogenic underplating deduced from both the strongly reflective and layered lower crust observed on seismic sections (white lines; from Rey (1993) and Banda et al. (1993)) and from gabbro and granulites outcrops or xenoliths (violet dots from Petri et al. (2017)). d) Interpreted seismic section through the Variscan orogenic area (from Bois qt al. (1989); see map for location); VT: Variscan Thrust; VF: Variscan Front; the brown shading highlights the layered and highly reflective lower crust that is interpreted as either magmatic underplate or granulite-facies metamorphosed rocks. 


\section{Geological setting}

\subsection{Orogenic Collapse in Western Europe}

Following the termination of the Paleozoic convergence in Western Europe, the Caledonian and Variscan orogens collapsed (Dewey, 1988; Burg et al., 1994, and references therein). Gravitational re-equilibration of the over-thickened lithosphere was achieved via the formation of normal faults, extensional detachment faults and ductile shear zones in upper- to mid-crustal levels (Andersen, 1998, and references therein) and by ductile flow of the thermally weakened lower crust at deeper levels (Rey et al., 2001).

Regional post-orogenic magmatism and underplating is recorded during the Devonian around 390-400 Ma in the Caledonian domain of northern Scotland and Ireland (Atherton and Ghani, 2002). This magmatic event is interpreted to be a consequence of the Iapetus slab breakoff during/after continental collision, which induced partial melting of the subcontinental lithospheric mantle and lower continental crust (Atherton and Ghani, 2002; Neilson et al., 2009). In contrast, the orogenic collapse of the Scandinavian Caledonides was largely devoid of magmatic activity (Meissner, 1999; Fossen et al., 2014). The collapse of the Variscan orogen of Western Europe was followed by a major magmatic event that affected most of the orogenic lithosphere. This magmatic event was manifested from late- to post-orogenic magmatism and high temperature regional metamorphism in Iberia, France, southern Britain, Central and Western Alps, the Bohemian Massif, Corsica-Sardinia and the Ivrea zone in Northern Italy from late Carboniferous to Permian time (e.g. Schaltegger and Corfu, 1995; Buzzi and Gaggero, 2008; Rosas et al., 2008; Timmerman et al., 2009; Petri et al., 2017; Augier et al., 2015; Rossi et al., 2015; Vavra et al., 1996, Figure 1c). The melts were essentially sourced by the partial melting of the underlying asthenospheric mantle (Costa and Rey, 1995; Rampone et al., 1996) such that the underplated area is largely underlain by zones of depleted mantle (Müntener et al., 2004; McCarthy and Müntener, 2015; Picazo et al., 2016). Partial melting of the asthenospheric source occurred in the spinel and garnet stability fields, which suggests melting depths between 40-70 km (McCarthy and Müntener, 2015; Picazo et al., 2016).

\subsection{Architecture of the European Lithosphere}

Bois et al. (1989) and Rey (1993) observed that, in the Variscan domain of 
Western Europe, the continental crust is usually characterized by a layered and highly reflective lower crust of 2 to $4.5 \mathrm{~s}$ TWT thickness on seismic sections (Figures 1c and d). These authors interpreted the layered reflective lower crust as magmatic underplating and/or granulite-facies metamorphism of the continental crust. Assuming a crustal seismic velocity of $6 \mathrm{~km} \cdot \mathrm{s}^{-1}$, the thickness of this layer would range between 6 and $13 \mathrm{~km}$. This thickness estimate is consistent with field observations by Fountain (1976), who estimated the Permian mafic lower crust that crops out in the Ivrea zone to be approximately $8 \mathrm{~km}$ thick.

The large extent of the underplating event is well recognized in the Variscan domain of central and southern Western Europe, characterized by a significant amount of evidence suggests the existence of a widespread mafic lower crust of Permian age. Evidence for this crust includes include mafic lower crust outcrops and xenoliths, widespread magmatic intrusions of Permian age in the upper- and middle-crust (Schaltegger and Corfu, 1995; Meissner, 1999;

Schuster and Stüwe, 2008) and numerous seismic sections showing a layered and highly reflective lower crust over a length of more than $100 \mathrm{~km}$ (Bois et al., 1989; Rey, 1993, Figures 1c and d).

The extent of the Variscan mafic underplate is less well-constrained in Britain due to both the lack of outcrop or xenoliths and the overprint by magmatic additions related to the younger North-Atlantic breakup. Seismic sections show a layered and highly reflective lower crust at least up to the Iapetus Suture (Bois et al., 1989).

North of the Iapetus suture, widespread plutons of Devonian age crop out in northern Scotland and Ireland (Atherton and Ghani, 2002). Although this late- to post-Caledonian magmatic activity was much less extensive than that in the Variscan domain and the source of the melt was shallower (lower crust to subcontinental lithospheric mantle according to Neilson et al., 2009), it has presumably underplated the lower continental crust and depleted the shallowest part of the subcontinental lithospheric mantle on a regional scale. The reflective lower crust visible on seismic sections in northern Scotland and Ireland (e.g. DRUM seismic line of the BIRPS Atlas) can be explained either by this late-Caledonian magmatic event, or by the early Eocene magmatic event related to North Atlantic breakup.

Despite the large-scale extent of the Permian magmatic event in the Variscan domain, underplating is presumably discontinuous and increasingly so away from the orogen center. 
By Permian time, the thick ( $>50-60 \mathrm{~km}$ ) Variscan crust was most likely thinned to about 30-35 km across Western Europe and the lithosphere was thermally and isostatically equilibrated by late Triassic (Müntener et al., 2000). Progressive cooling of the post-orogenic lithosphere led to the incorporation of depleted mantle zones, which belonged formerly to the asthenosphere, into the lithospheric mantle. By Jurassic time, the geothermal gradient was still relatively high in the Variscan orogenic area, with a Moho temperature of $\sim 550-650{ }^{\circ} \mathrm{C}$ (Müntener et al., 2000), while it ranged between 350-500 ${ }^{\circ} \mathrm{C}$ in the older Caledonian orogenic domain (Čermák and Bodri, 1986).

A first-order approximation of the architecture of a 'classical' orogenic lithosphere that did not experience a massive post-orogenic magmatic event, (e.g. the Caledonian lithosphere of Norway-Greenland) is presented in Figure 2a. A first-order approximation of the architecture of an orogenic lithosphere that underwent an intense post-orogenic magmatic event with mafic underplating of the crust (e.g. the Variscan orogenic lithosphere) is shown in Figure 2b.

\subsection{The Alpine Tethys and North Atlantic Rift Systems}

During the Jurassic, about 100 My after the termination of the Variscan orogeny, the orogenic lithosphere of Western Europe started to undergo significant thinning related to the formation of the future Alpine Tethys and North Atlantic ocean basins (Chenin et al., 2015, and references therein). Whereas the rifts largely followed the Caledonian orogenic sutures and/or former fold-and-thrust belts between Norway and Greenland (Wilson, 1966; Erratt et al., 1999; Williamson et al., 2002), most of the Variscan orogenic structures of Western Europe remained little affected by the later Mesozoic rifting. The Alpine Tethys and the North Atlantic rift systems developed instead at the southern and western edges of the underplated orogenic lithosphere, respectively (Figures 1b and c; Frizon de Lamotte et al. (2011); Chenin et al. (2015)).

\section{$3 \quad$ Numerical Modeling Study}

In this study we investigate how the first-order remnants inherited from magmatic collapse may impact subsequent rifting, assuming various 
geothermal gradients of the lithosphere. To perform the experiments we used an extended version of the numerical code PARAVOZ called FLAC (Fast Lagrangian Analysis of Continua; Cundall (1989); Poliakov et al. (1993); Lavier et al. (2000); Lavier and Manatschal (2006)) with the bi-minineralic parametrization developed by Jammes et al. (2015); Jammes and Lavier (2016). The brittle part of the lithosphere is modeled as an elastoplastic material with a Mohr-Coulomb yield criterion (Lavier, 2002):

$$
\tau=C+\tan (\phi) \sigma_{n}
$$

where $\tau$ is the shear stress at yield, $\mathrm{C}$ the cohesion, $\phi$ the friction angle, and $\sigma_{n}$ the normal stress. To model localized faulting, materials undergo strain weakening that decreases both their cohesion and internal angle of friction from $C_{1}$ to $C_{2}$ and from $\phi_{1}$ to $\phi_{2}$ (see Table 1) until accumulated strain reaches $10 \%$, after which they remain at $C_{2}$ and $\phi_{2}$, respectively (Lavier et al., 2000). To model the viscous part of the lithosphere, we use the Maxwell viscoelastic constitutive equations. The deformation mechanism requiring the least energy or effective stress (second invariant of stress tensor) is favored. More detailed descriptions of the code can be found in Tan et al. (2012); Svartman Dias et al. (2015) and Jammes and Lavier (2016).

\subsection{Model Design}

The model (Figure 2) consists of an initially $400 \mathrm{~km}$ wide by $250 \mathrm{~km}$ deep continental domain extended at a constant velocity of $1 \mathrm{~cm} \cdot \mathrm{yr}^{-1}$ (full rate). The horizontal spatial resolution is $1 \mathrm{~km}$ and the vertical resolution is $750 \mathrm{~m}$ between 0 and $120 \mathrm{~km}$ depth, $1 \mathrm{~km}$ between 120 and $160 \mathrm{~km}$, and $1.8 \mathrm{~km}$ between 160 and $250 \mathrm{~km}$.

The $30 \mathrm{~km}$ thick continental crust has a granitic composition made of $40 \%$ quartz and $60 \%$ feldspar with randomly distributed (Jammes et al., 2015; Jammes and Lavier, 2016, and Table 1 for the physical parameters corresponding to each material). For the sake of simplicity, we model two distinct types of mantle as homogeneous materials assuming their structural inheritance has been essentially erased by thermal annealing associated with grain regrowth (Yamasaki et al., 2006). This mechanism is particularly efficient in the presence of subduction-related fluids (Aradi et al., 2017) so that we can reasonably assume that it occurs beneath orogens. The inherited mantle is olivine with a rheology intermediate between the dry and wet 


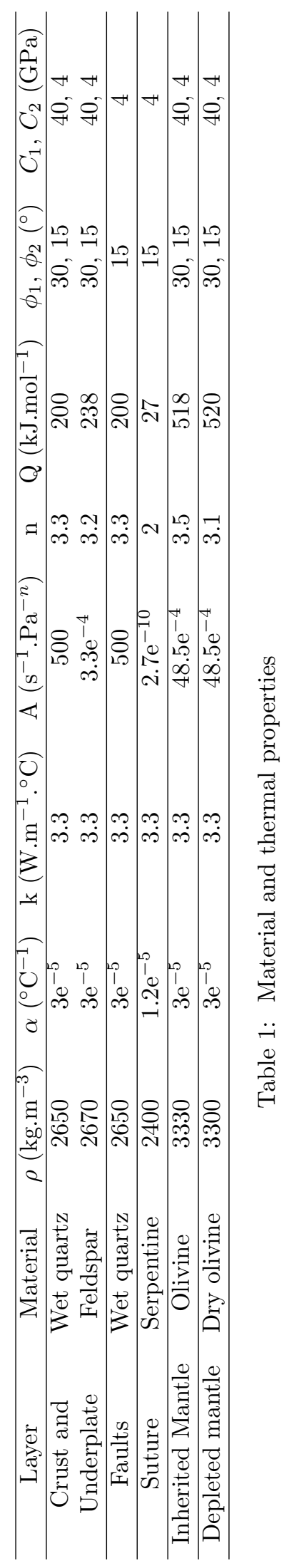


a) Reference Model 1

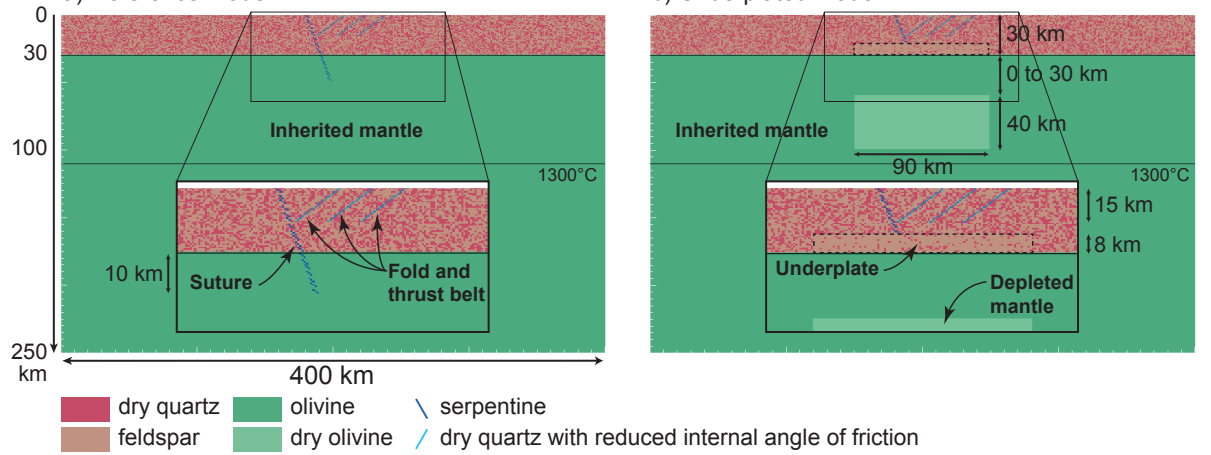

Figure 2: Architecture of the reference Model 1 (a) and underplated Model 2 (b). The base of the lithosphere corresponds to the isotherm $1300{ }^{\circ} \mathrm{C}$ (black line). Its depth varies between $110 \mathrm{~km}$ in the model with a Moho temperature of $500{ }^{\circ} \mathrm{C}$ and $95 \mathrm{~km}$ with a Moho temperature of $600{ }^{\circ} \mathrm{C}$.

end-members described by Hirth and Kohlstedt (1996) to approximate the behavior of a mantle that underwent both hydration by subduction fluids and depletion due to arc-related partial melting. When applicable, the zone of depleted mantle is modeled as dry olivine, which is stronger than the 'inherited' mantle (Figures 3a-d). The depleted mantle is slightly less dense than the encompassing fertile mantle (3,300 compared to $\left.3,330 \mathrm{~kg} \cdot \mathrm{m}^{-3}\right)$ as reported by Chenin et al. (2017). Note that our aim is to investigate the impact of plausible rheological contrasts rather than to model an actual inherited mantle flow law, which would require additional constrains from field and geochemistry studies.

The lithosphere-asthenosphere boundary is defined as the $1300{ }^{\circ} \mathrm{C}$ isotherm, which is displayed as a black line in each figure. Its initial depth varies from $110 \mathrm{~km}$ to $95 \mathrm{~km}$ depending on the geothermal gradient of the model considered. In all models, the basal heat flow is $14 \mathrm{~mW} \cdot \mathrm{m}^{-2}$. The surface heat flow is $50 \mathrm{~mW} \cdot \mathrm{m}^{-2}$ in models with a Moho at $500{ }^{\circ} \mathrm{C}, 60 \mathrm{~mW} \cdot \mathrm{m}^{-2}$ in models with a Moho at $550{ }^{\circ} \mathrm{C}$ and $80 \mathrm{~mW} \cdot \mathrm{m}^{-2}$ in models with a Moho at $600{ }^{\circ} \mathrm{C}$. We model a former orogenic domain by one 'suture' and a 'fold-and-thrust belt' in the model center. The suture is mimicked by a $1 \mathrm{~km}$ wide linear structure dipping at $60^{\circ}$ that follows the antigorite flow law from Amiguet et al. (2014), which represents one of the weakest phases (serpentine, talc, micas) existing in a suture zone. This 'suture zone' crosscuts the entire crust 
a)

$500^{\circ} \mathrm{C}$ Moho (Model 1-6)
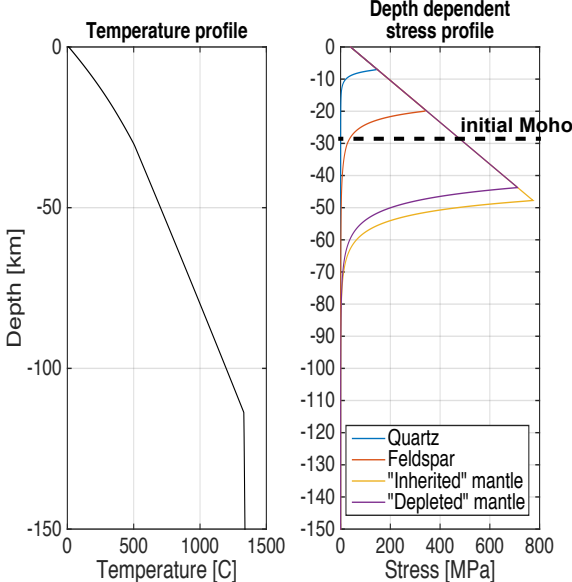

$600^{\circ} \mathrm{C}$ Moho (Model 8)

c)
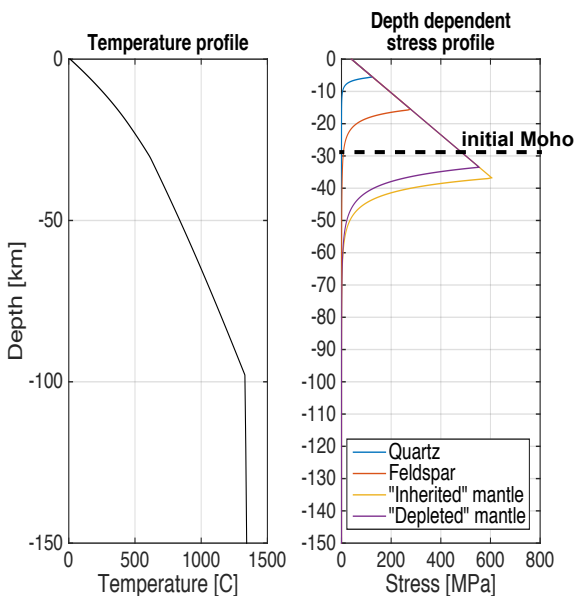

b)

$550^{\circ} \mathrm{C}$ Moho (Model 7)
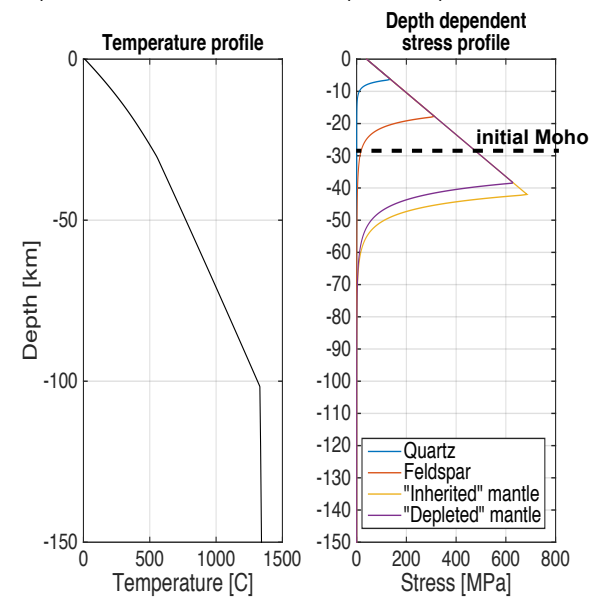

d) $500^{\circ} \mathrm{C}$ Moho $+300^{\circ} \mathrm{C}$ underplating (Model 9)

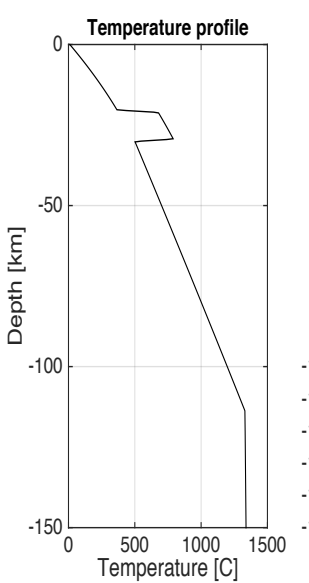

Depth dependent

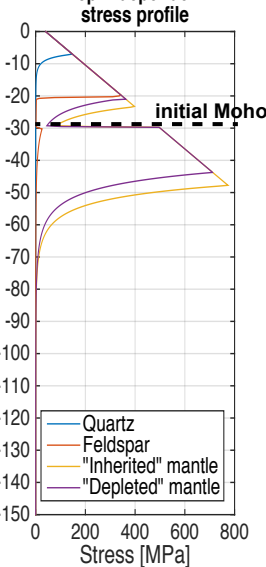

e) DM from 60 to $100 \mathrm{~km}$ (Model 4) f) DM from 50 to $90 \mathrm{~km}$ (Model 5)
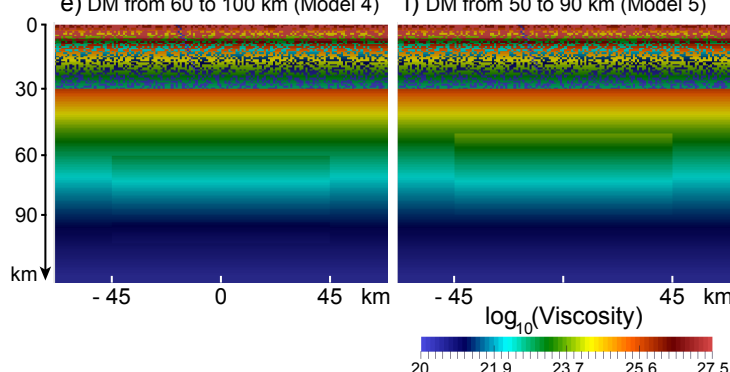

g) DM from 30 to $70 \mathrm{~km}$ (Model 6)

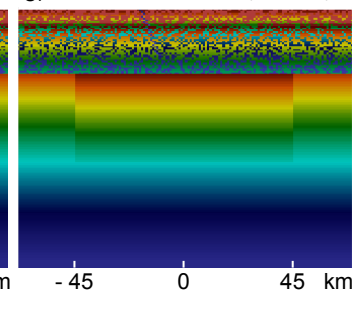
$25.6 \quad 27.5$

Figure 3: a-d) Depth dependent stress profiles of the four modeled rheological phases under different geothermal gradients. All depth-dependent stress profiles are for a reference strain rate of $10^{-15} \cdot \mathrm{s}^{-1}$. e-g) Viscosity field in the top $100 \mathrm{~km}$ of the central region of Model 4-6; DM: depleted mantle. 
and the top $10 \mathrm{~km}$ of the lithospheric mantle in the reference model. Deeper, we assume that structural inheritance has been essentially erased (Yamasaki et al., 2006; Aradi et al., 2017). The fold-and-thrust belt is mimicked by three linear weak zones that extend down to the brittle-ductile transition $(15 \mathrm{~km})$. These 'faults' dip at $45^{\circ}$ in the opposite direction to the suture. They have a wet quartz rheology with reduced cohesion and angle of friction (Table 1). We model the result of mafic underplating or granulite facies metamorphism of the lower crust (see section 2.2) as an $8 \mathrm{~km}$ thick and $90 \mathrm{~km}$ wide body comprised of $10 \%$ quartz and $90 \%$ feldspar at the base of the crust beneath the orogenic domain. The $8 \mathrm{~km}$ thickness is a lower estimate of underplate thickness based on both seismic interpretations by Bois et al. (1989) and Rey (1993), and P-wave velocities and lower crust outcrops in the Ivrea Zone (Fountain, 1976). On the seismic sections of Bois et al. (1989), the horizontal extent of the strongly reflective lower crust is usually more than $100 \mathrm{~km}$. Here we chose arbitrarily a $90 \mathrm{~km}$ width to keep the model at a reasonable size with the lithospheric heterogeneities far enough from the model edges to avoid numerical 'edge effects'. In models with a mafic underplate, the suture zone terminates at the top of the underplate, as expected for the Variscan domain (Figure 1d). Note that replacing the $10 \%$ quartz by $10 \%$ pyroxene ( gabbroic composition) would result in an even stronger heterogeneity, favoring even more delocalization of the deformation.

The underplated region is underlain by a $90 \mathrm{~km}$ wide by $40 \mathrm{~km}$ thick zone of depleted mantle (strong dry olivine). The width of the depleted mantle is thus similar to that of the overlying mafic body. We chose a thickness of $40 \mathrm{~km}$ for the depleted mantle zone based on the estimation that beneath mid-oceanic ridges the thickness of the depleted mantle ranges from 40 to $200 \mathrm{~km}$ (Anderson, 2006), assuming that partial melting processes are comparable in both cases. The chosen size of the depleted mantle zone is a minimum since, if we assume that the 8 x $90 \mathrm{~km}$ underplated mafic body was formed as a result of $12 \%$ partial melting of the asthenosphere, the lateral extent of a corresponding $40 \mathrm{~km}$ thick depleted mantle region should be of the order of $121 \mathrm{~km}$ (using the densities of Table 1). As our aim is to investigate whether underplating and/or depletion may be important in controlling the localization of extension, we chose to study the 'least favorable' case. We set the initial depth of the top of the depleted region to $60 \mathrm{~km}$ based on evidence for partial melting in the spinel-garnet stability field (see section 2.2), and thus its base to $100 \mathrm{~km}$. We also test the case of a depleted mantle zone of similar size 
located directly beneath the crust (i.e. between 30 and $70 \mathrm{~km}$ depth), which would represent a former magmatic arc (see DeBari and Greene (2011) for examples).

Note that neither the generation and migration of melts, nor the effect of erosion or sedimentation are included in our experiments, and the rheology of all model phases are simplified compared to nature. As a result, the absolute values for basin depths and widths, as well as the timing of rifting should be considered with care when compared with the history of actual rift systems. Our reference model (Model 1; Figures 4 and 5) has a Moho temperature of $500{ }^{\circ} \mathrm{C}$, one 'suture zone' and three 'faults' but is devoid of both underplate and depleted mantle (Figure 2a). Such a model may represent the first-order architecture of an orogenic lithosphere whose orogenic collapse lacked extensive magmatism, as for example the Caledonides of Norway-Greenland. We first consider a series of models (Models 2 to 6 in Figures 4 and 5) with different distributions of crustal and mantle heterogeneities under the same geothermal gradient as in Model 1 (Moho temperature $500{ }^{\circ} \mathrm{C}$ ). Model 2 comprises both mafic crustal underplating and a deep (60 to $100 \mathrm{~km}$ ) zone of depleted mantle (Figure 2b). Model 3 has only crustal underplating. Model 4, 5 and 6 have only a zone of depleted mantle located between 60 and $100 \mathrm{~km}$, 50 and $90 \mathrm{~km}$ and 30 and $70 \mathrm{~km}$ depth, respectively.

In the second series of models (Models 7 to 9 in Figures 6 and 7), we compare models with similar lithological architectures as Model 2 (Figure 2b) but different geothermal gradients (Figures 3b-d). In Models 2, 7 and 8, the lithosphere is initially thermally equilibrated and the temperature of the Moho ranges from $500{ }^{\circ} \mathrm{C}$ (Model 2), to $550{ }^{\circ} \mathrm{C}$ (Model 7) and to $600{ }^{\circ} \mathrm{C}$ (Model 8). These models are used to represent cases where the time lag between the magmatic event and the onset of rifting was sufficient for horizontal re-equilibration of the temperature (i.e. > $100 \mathrm{My}$; Jaupart and Mareschal (2007)). With Model 9, we investigate the case when rifting starts over a young lithosphere that has not thermally re-equilibrated by setting the Moho temperature to $500{ }^{\circ} \mathrm{C}$ and adding a $300{ }^{\circ} \mathrm{C}$ thermal anomaly in the underplate (Figure 3d). 


\section{Results}

\subsection{Influence of the rheological composition}

In this section, we test the influence of strong heterogeneities within the lower crust and/or the lithospheric mantle beneath crustal weaknesses on the localization of deformation during extension. All models have the same initial geothermal gradient (Moho temperature $500{ }^{\circ} \mathrm{C}$ ).

\subsubsection{Reference Model 1: No Underplating, no Depleted Mantle}

In the reference Model 1, prior to $0.4 \mathrm{My}$, deformation is widely distributed within the crust with a slightly higher strain rate at the suture zone and the two adjacent antithetic 'faults' of the 'fold-and-thrust belt' (not shown). In the mantle, no significant strain rate is recorded before $0.3 \mathrm{My}$, after which deformation focusses at the suture. At $0.4 \mathrm{My}$, deformation in the crust and mantle is essentially localized at the suture and two adjacent faults, although some of the initial crustal shear zones remain slightly active (Figures 4 and 5). After 1 My of extension, deformation is essentially accommodated by brittle faulting at the suture and at the two right-hand side faults of the fold-and-thrust belt in the uppermost 10-12 $\mathrm{km}$ of the crust and at the suture in the uppermost 10-13 km of the mantle (Figure 4). In between, anastomosing shear zones develop in the lower crust (Figure 5). As extension progresses, two new pairs of conjugate shear zones form within the crust to the left of the suture, while the suture zone and two right-hand side faults are still actively deforming (Figures 4 and 5 at $2 \mathrm{My}$ ). All these shear zones remain active and a new one forms to the right of the fold and thrust belt between 3 and 4 My (Figures 4 and 5 at $4 \mathrm{My}$ ). By $4 \mathrm{My}$ the rift basin reaches a depth of more than $6 \mathrm{~km}$. As extension continues, upwelling of the asthenosphere focuses deformation between the suture and left-hand side fault of the fold-and-thrust belt, while the other shear zones are progressively abandoned. The suture is intensively deformed and becomes progressively offset to the left of the asthenosphere upwelling. Crustal separation is achieved after $14 \mathrm{My}$ of extension, between the suture and the fold-and-thrust belt. The margins are both $\sim 100 \mathrm{~km}$ wide and largely symmetrical despite the asymmetric distribution of the inherited weaknesses. The $1300{ }^{\circ} \mathrm{C}$ isotherm reaches a depth of $35 \mathrm{~km}$ at the end of the simulation (Figure 4). 

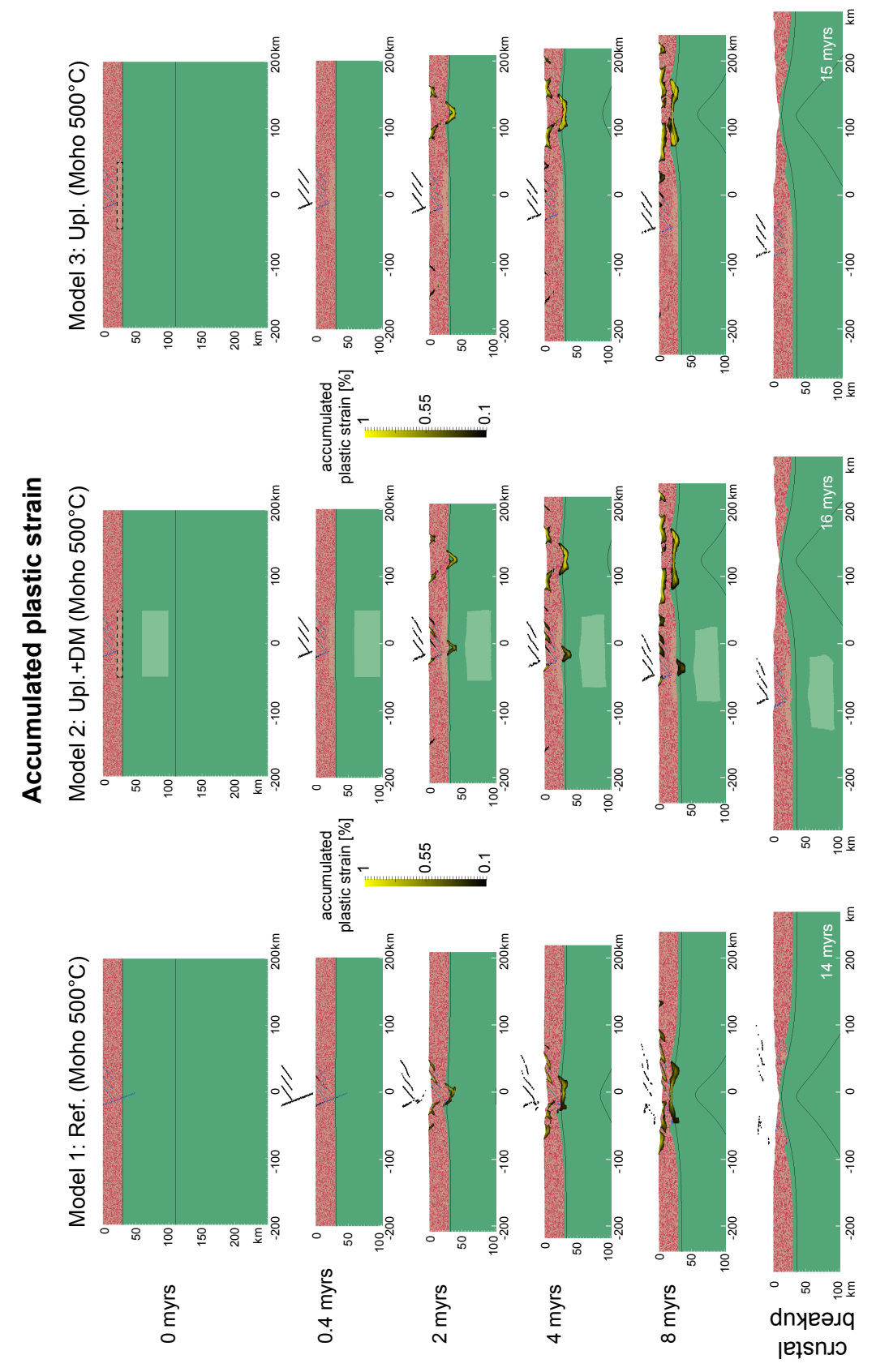

Figure 4: CONTINUED 


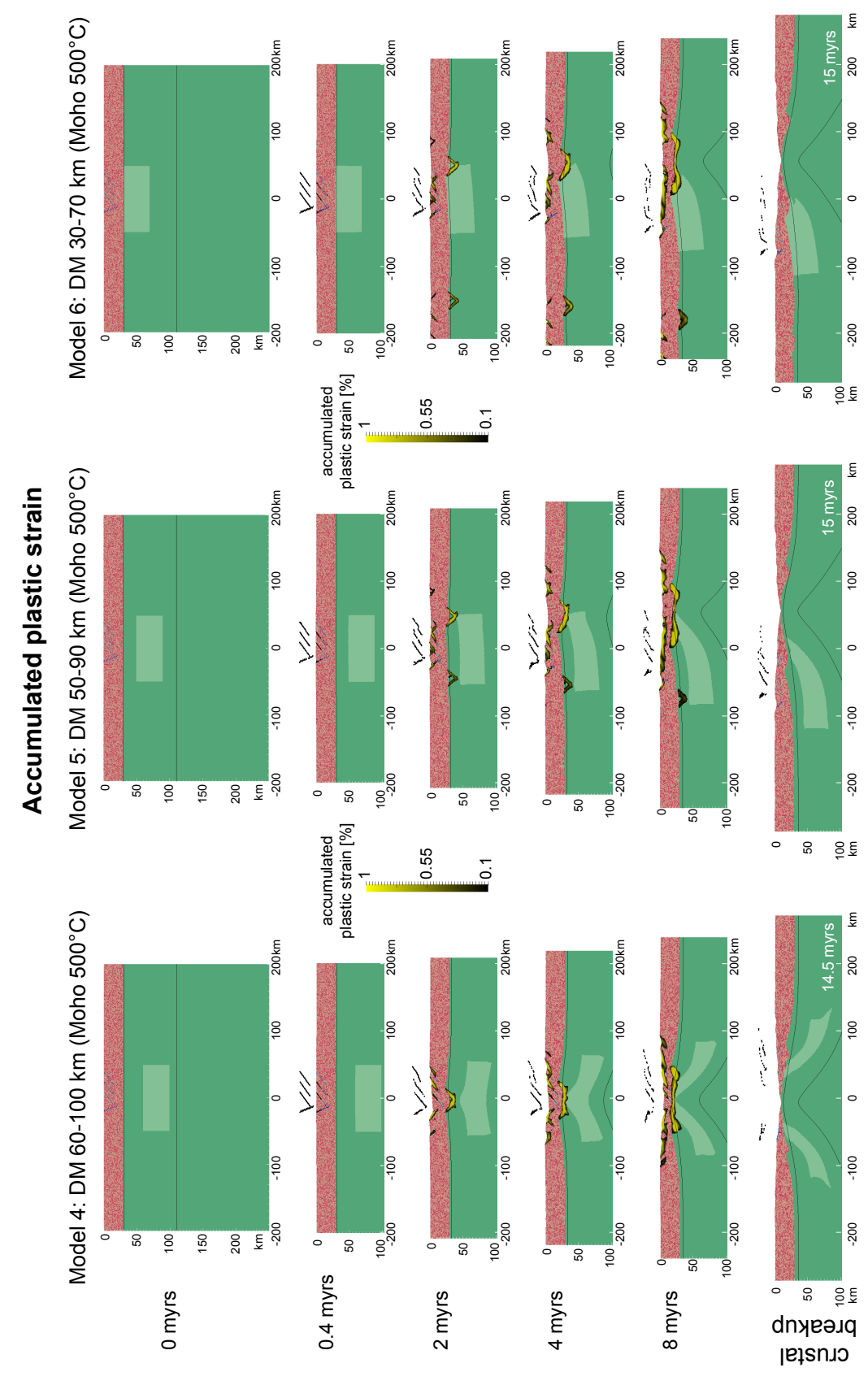

Figure 4: Rheological phases and plastic strain (>0.1\%) distribution in Models 1-6. Plastic strain is not shown on the last panel for better phases visualization. The trace of the inherited 'suture' and 'faults' is redrawn above each panel. Ref.: Reference model; Upl.: mafic underplating of the crust; DM: depleted mantle. 

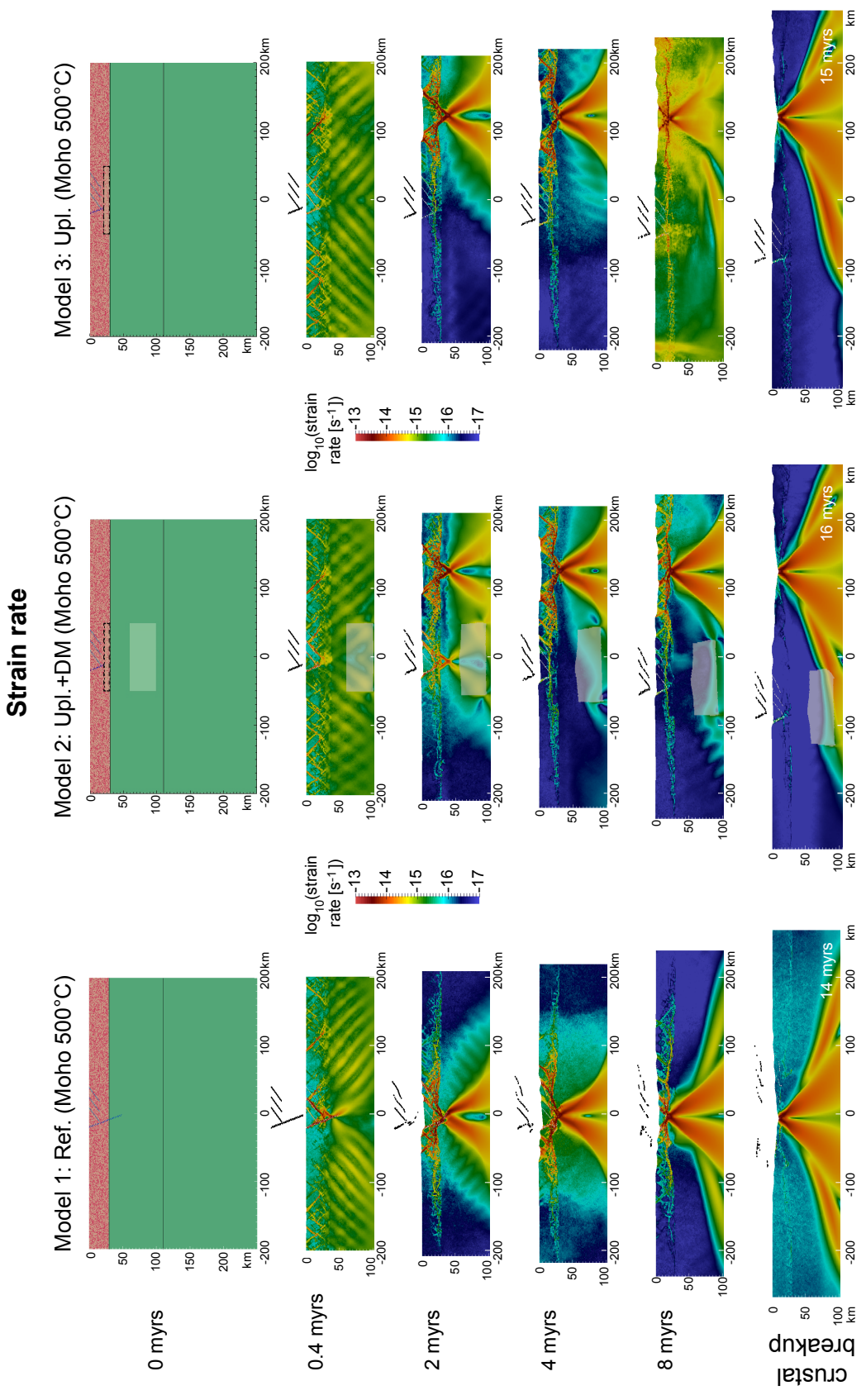

Figure 5: CONTINUED. 

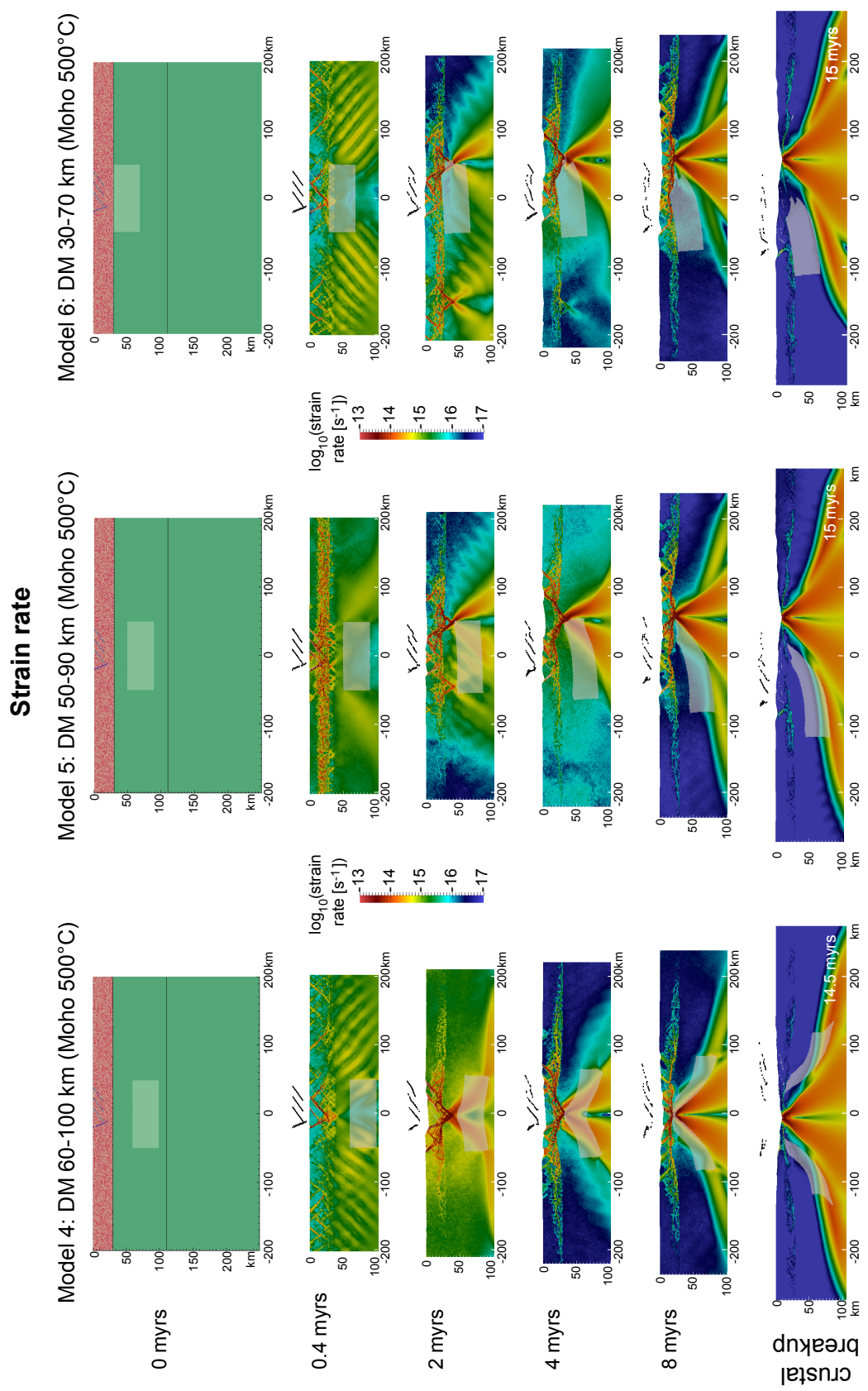

Figure 5: Strain rate evolution in Models 1-6. The depleted mantle zone is superimposed in white for location and the trace of the inherited 'suture' and 'faults' is redrawn above each panel. Ref.: Reference model; Upl.: mafic underplating of the crust; DM: depleted mantle. 


\subsubsection{Model 2: Mafic Underplating and Depleted Mantle}

In Model 2, deformation is widely distributed within the crust after 0.5 My extension but the suture zone and adjacent faults deform with a slightly higher strain rate than average (Figure 5). After 1 My of extension, deformation is partitioned between the central orogenic region and a region $\sim 130 \mathrm{~km}$ to the right, which we refer to as the 'offset rift'. At this time, intense brittle deformation occurs in the uppermost 10-12 km of the crust and in the uppermost 10-13 km of the mantle at both locations (Figure 4). While anastomosing shear zones are well-developed in the lower crust of the offset rift, they are largely lacking in the central 'underplated' part of the model where the proportion of feldspar over quartz is larger in the lower crust (Figure 5).

The suture zone and adjacent faults remain actively deforming during the first 3 My of extension, forming a $\sim 1 \mathrm{~km}$ deep basin within the former orogenic area. As extension progresses, the orogenic region is progressively abandoned in favor of the offset rift. This triggers the upwelling of the underlying mantle away from the former orogenic area, and the underlying depleted mantle remains largely undeformed. Crustal separation occurs after $\sim 15 \mathrm{My}$ of extension in the offset basin. The margin architecture, timing of crustal separation and depth to the $1300{ }^{\circ} \mathrm{C}$ isotherm at the end of the simulation are comparable to those of Model 1.

\subsubsection{Model 3: Mafic Underplating Only}

The evolution of Model 3 is similar to that of Model 2 except that no significant extension occurs at the inherited structures (Figures 4 and 5). After 1 My of extension, a pair of conjugate brittle shear zones rooting in well-developed lower crustal anastomosing shear zones forms $\sim 130 \mathrm{~km}$ to the

right of the orogenic region. Beneath, one pair of shear zones develops, leading to upwelling of the underlying mantle and localization of the deformation in this offset basin. Crustal separation occurs after $\sim 15 \mathrm{My}$ of extension in the offset basin. The margin architecture, timing of crustal separation and depth to the $1300{ }^{\circ} \mathrm{C}$ isotherm are comparable to those of Model 1 and 2 . 


\subsubsection{Model 4: Depleted Mantle Only (60-100 km)}

The evolution of Model 4 is similar to that of our reference Model 1 (Figures 4 and 5). During early stages of extension, a pair of conjugate shear zones forms both in the upper crust and uppermost mantle within the orogenic area, with well-developed lower crustal anastomosing shear zones between them. In Model 4, the lighter depleted mantle located beneath the orogenic domain is progressively exhumed towards the surface as the weaker overlying 'inherited' mantle is preferentially thinned. By $8 \mathrm{My}$, depleted mantle is juxtaposed with relatively thick crust $(>20 \mathrm{~km})$ in the central rift area. At the time of crustal separation, the depleted mantle partially underlies parts of the hyperextended crust but is not exhumed to the seafloor (Figure 4).

\subsubsection{Model 5: Depleted Mantle Only (50-90 km)}

In Model 5, the initially depleted mantle zone is located from $50 \mathrm{~km}$ to $90 \mathrm{~km}$ depth (Figures 4 and 5). In this model, early crustal deformation is accommodated by shear zones located at the suture zone and orogenic weaknesses in the brittle upper crust and well-developed anastomosing shear zones in the underlying lower crust. From 1 My onward, two pairs of conjugate shear zones develop in the uppermost brittle mantle, one above each edge of the depleted mantle zone. The left-hand pair of shear zones is abandoned after $\sim 3 \mathrm{My}$ of extension in favor of the right-hand pair. As extension progresses, deformation becomes centered on the right-hand edge of the depleted mantle zone. As a result, the rift develops $50 \mathrm{~km}$ to the right of the model center and crustal separation occurs outside the 'orogenic area'.

\subsubsection{Model 6: Depleted Mantle Only (30-70 km)}

When the zone of depleted mantle is initially juxtaposed against the base of the crust as in Model 6 (Figures 4 and 5), the inherited weaknesses are initially significantly reactivated. Anastomosing shear zones form at lower crustal depths along the entire model. From 1 My extension onward, two pairs of conjugate shear zones form in the uppermost mantle: one forms at the right-hand edge of the depleted mantle zone, and a second forms $150 \mathrm{~km}$ to the left of the model center. Well-developed anastomosing shear zones only remain above these two upper mantle shear zones. Both regions remain actively deforming during the first 2.5 My of extension. After that time, 
deformation at the right-hand side rift basin takes over while the left-hand side basin is abandoned. Crustal separation is achieved after $15 \mathrm{My}$ of extension $60 \mathrm{~km}$ to the right of the model center without exposure of depleted mantle to the seafloor.

\subsubsection{Interpretation}

In our reference model with only inherited weaknesses (Model 1; Figure 4), the suture is not the locus of the final crustal separation despite it having the weakest rheology and the largest extent. Crustal separation occurs between the suture and the adjacent 'fold-and-thrust belt'. The reason is that extension of the crust is at first accommodated by reactivation of the suture and the central and right-hand side antithetic 'faults' of the 'fold-and-thrust belt'. As extension progresses, the lithosphere is thinned beneath the 'orogenic domain' and the underlying asthenosphere starts rising. As this low density upwelling mantle rises, it controls the location of extension (Huismans et al., 2001). In natural settings, upwelling asthenosphere is likely to cause melting by decompression, generating a vertical weakening of the lithosphere associated with melt extraction processes (fluid pressure-induced fracturation and heat transport), which would further increase the upwelling rate (Keller et al., 2013; Keller and Katz, 2016).

The final rift configuration of Model 1 can be compared to the location of the northern North Atlantic rift with respect to the suture and fold-and-thrust belt of the Norwegian-Greenland Caledonides (Figure 1a). Note that the evolution and final margin architecture of a comparable model where the suture is limited to the top $22 \mathrm{~km}$ of the crust (i.e. equivalent to Figure $2 \mathrm{~b}$ without underplating and depleted mantle) is similar to that of Reference Model 1 (see Model 10 in Appendix, Figure 8).

According to our model results, under a moderate geothermal gradient (Moho temperature $\sim 500{ }^{\circ} \mathrm{C}$ ), the existence of an underplated mafic body in the lower crust or a shallow zone of depleted mantle beneath a region comprising weak heterogeneities is likely to prevent protracted deformation of these weaknesses during extension (Models 2, 3, 5 and 6 in Figure 4). The reason is that the high proportion of feldspar relative to weaker quartz hampers the development of anastomosing shear zones in the lower crust, and thus renders linkage between crustal and mantle deformation difficult. As a consequence, deformation will preferentially focus at weak spots generated by the random 
quartzo-feldspathic material distribution within the crust, at a place where crustal and mantle deformation can be easily linked through lower crustal anastomosing shear zones, even though this relatively weak spot is significantly stronger than any of the inherited weaknesses.

Comparison of Reference Model 1 to Model 4, which comprises only a zone of depleted mantle between 60 and $100 \mathrm{~km}$ depth and no underplating (Figures 4 and 5) suggests that deep $(>\sim 60 \mathrm{~km})$ mantle heterogeneities have little impact on the location, evolution and timing of rifting. This can be explained by the small difference between the 'inherited' and 'depleted' mantle flow laws at a depth of $60 \mathrm{~km}$ or higher (Figure 3a). However, comparing the early stages of Model 2 (underplating plus depleted mantle) with Model 3 (underplating only) in Figure 5 highlights that the existence of a depleted mantle zone has an impact on rifting localization. Indeed, the slightly increased viscosity of the depleted mantle zone with respect to the surrounding mantle in Model 2 (Figure 3e) slightly perturbs the stress field (not shown) beneath the orogenic area. This allows for longer reactivation of the initial suture and faults in Model 2 compared to Model 3. Deep mantle heterogeneities may thus act as 'stress shades' between the overlying crust and underlying mantle by damping stress transmission between them due to their slightly higher viscosity. Comparing Model 3 (mafic underplating only) to Model 6 (shallow 30-70 km depleted mantle only; Figures 4 and 5) highlights that deformation localizes in a different way depending on whether the strong heterogeneity is located within the lowermost crust or uppermost mantle. The 'suture and faults' are significantly reactivated in the absence of underlying mafic underplate because deformation can be transmitted between them and the upper mantle through a semi-brittle lower crust. In contrast, they are immediately abandoned when the underlying lower crust is strong. In both models, crustal separation occurs outside the orogenic area, $\sim 120 \mathrm{~km}$ to the right of the model center in Model 3, similar to in Model 2 (underplating and depleted mantle between 60 and $100 \mathrm{~km}$ ), while crustal separation occurs $\sim 60 \mathrm{~km}$ to the right in Model 6 . Comparing Model 5 (depleted mantle between 50 and $90 \mathrm{~km}$ depth) and 6 (depleted mantle between 30 and $70 \mathrm{~km}$ depth; Figures 4 and 5) highlights that the location of plastic deformation is relatively similar independent on the location of the (shallow) depleted mantle zone: in both cases, a pair of conjugate shear zones located in the top 10-13 km of the mantle above or at the right-hand side edge of the depleted mantle zone localize most of extension within the mantle. This arises from the fact that heterogeneities are more 
prone to necking/localization of deformation when embedded in a stiff layer compared to a pliable layer (Chenin and Beaumont, 2013). Here the uppermost part of the mantle is the strongest and stiffest layer of the model, and the second layer is the top $20 \mathrm{~km}$ of the crust (Figure $3 \mathrm{a}$ ). When a mantle heterogeneity is within or close enough to this layer (e.g. depleted mantle zone of Model 5 or 6 ), extension will seed at or atop this layer. When there is no heterogeneity within the mantle or when it is deep enough so that the encompassing mantle is weak and 'pliable', as in Model 4, it will be ignored and the heterogeneities contained in the crust will control the location of necking. In both models, crustal separation occurs $\sim 60 \mathrm{~km}$ to the right of the model center.

Our dynamic numerical modeling results are generally consistent with the conclusions derived from the analog experiments of Cappelletti et al. (2013) that upper mantle breaching and crust-mantle deformation linkage occurs in an area devoid of strong lower crust. However, our models highlight that deformation localizes at or above the upper edges of the strong heterogeneity only when located in the shallowest part of the subcontinental lithospheric mantle (up to $\sim 50 \mathrm{~km}$ depth), while it localizes further away when the strong heterogeneity is located within the lower crust. We notice that the location of crustal separation depends on the stiff layer that contains the heterogeneity, consistent with the conclusions from Chenin and Beaumont (2013).

\subsection{Impact of Geothermal Gradient}

In the following sections, we compare Model 2 (i.e. Variscan-type architecture, Figure 2b; Moho temperature $500^{\circ} \mathrm{C}$ ) with models having the same material distributions, but varying initial geothermal gradients (see section 3.1 ).

\subsubsection{Model 7: Moho $550{ }^{\circ} \mathrm{C}$}

Comparing Model 7 (Moho temperature $550{ }^{\circ} \mathrm{C}$; Figures 6 and 7) with Model 2 (Moho temperature $500{ }^{\circ} \mathrm{C}$; Figures 4 and 5) highlights that orogenic structures remain actively deforming slightly longer when the geothermal gradient is higher ( $\sim 4 \mathrm{My}$ in Model 7 versus 2 My in Model 2). In both models, plastic deformation is similar in the upper crust: anastomosing shear

zones hardly form in the central (underplated) part of the model in contrast to the adjacent lower crust. In the mantle of Model 7 , high strain rates are predicted along both vertical sides of the depleted mantle zone from 0.1 My 


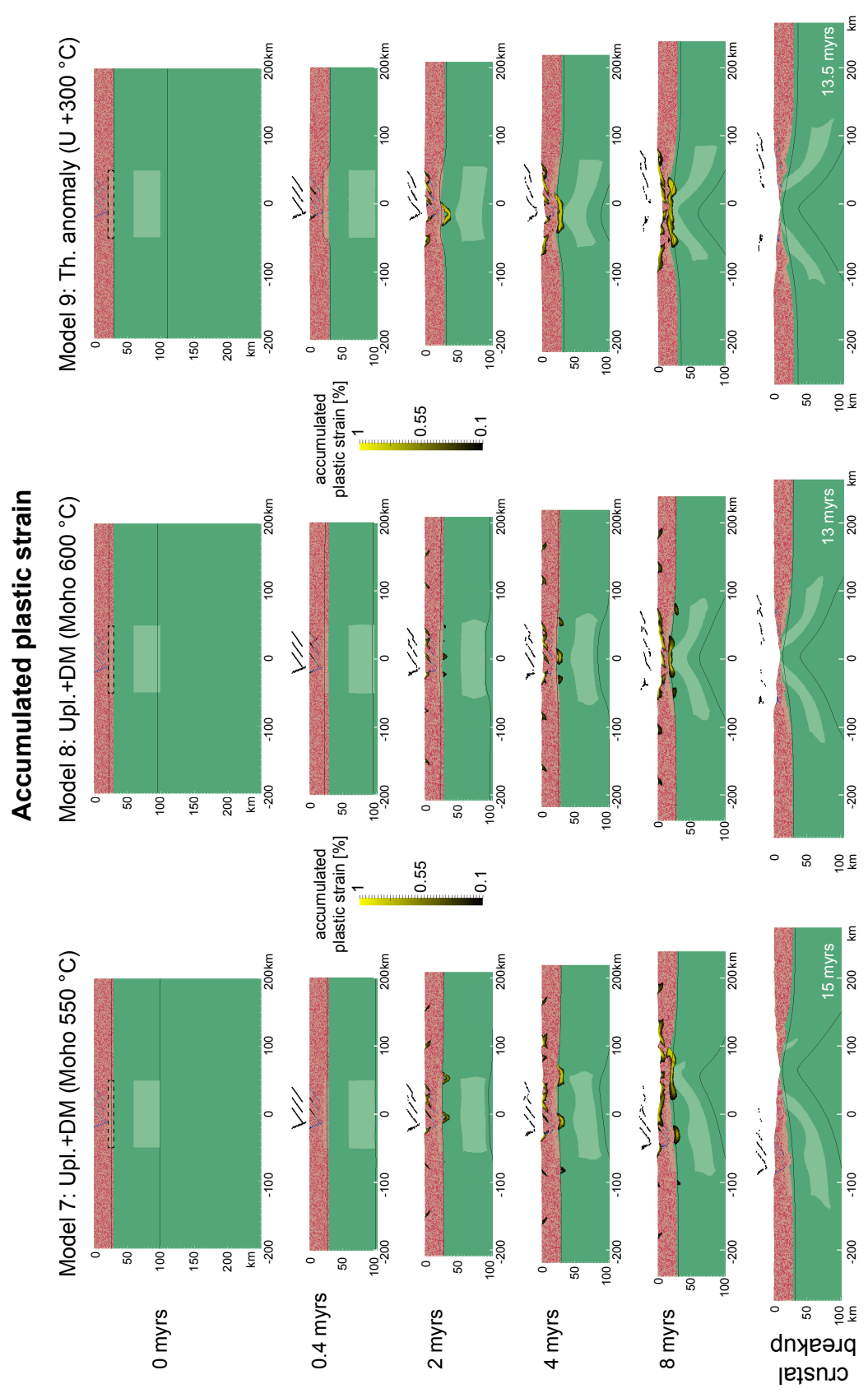

Figure 6: Rheological phases and plastic strain $(>0.1 \%)$ distribution in Model 7-9. Plastic strain is not shown on the last panel for better phases visualization. DM: depleted mantle; Upl.: mafic underplating of the crust; $\mathrm{T}^{\circ}$ anom.: model with a mafic underplating of the crust $300{ }^{\circ} \mathrm{C}$ hotter than the surrounding crust. 

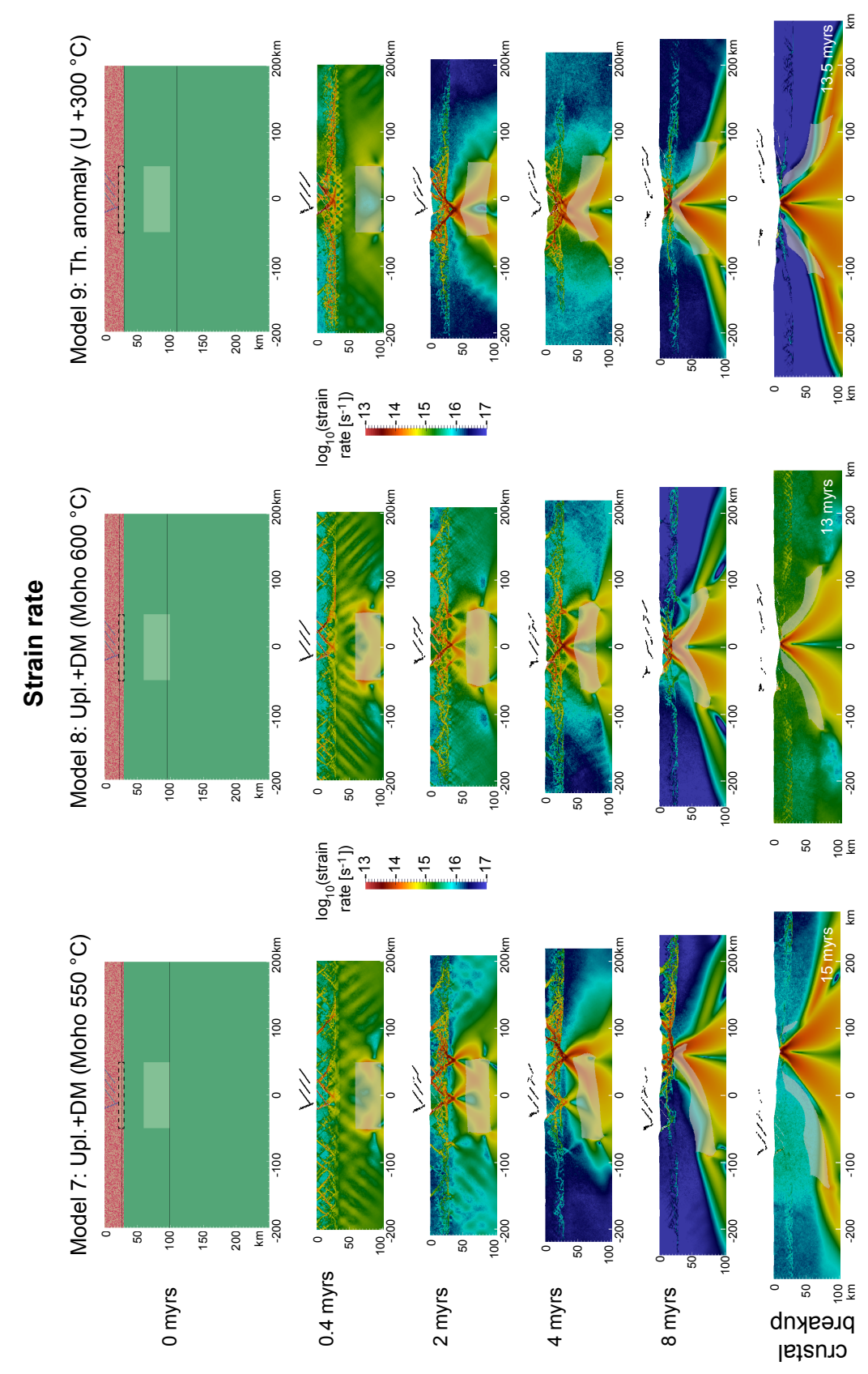

Figure 7: Strain rate evolution in Model 7-9. The depleted mantle and weak structures ('suture' and 'fold-and-thrust belt') are superimposed in white for location. DM: depleted mantle; Upl.: mafic underplating of the crust; $\mathrm{T}^{\circ}$ anom.: model with a mafic underplating of the crust $300^{\circ} \mathrm{C}$ hotter than the surrounding crust. 
extension onward, whereas high strain rates appear later (0.2 My) and are less intense in Model 2. In Model 7, the high strain rate zone along the right-hand side edge of the depleted mantle links with a pair of conjugate shear zones that form in the overlying brittle part of the mantle. These upper mantle shear zones are connected to the deformation occurring at the sites of the initial suture and faults. As a result, the rift develops above the right-hand side edge of the depleted mantle in a comparable way as in Model 5 (no underplating; depleted mantle between 50 and $90 \mathrm{~km}$; Figures 4 and 5). In Model 7, crustal thinning and upwelling of the asthenospheric mantle adjacent to the orogenic domain brings part of the depleted mantle towards the surface. Depleted mantle is eventually juxtaposed next to the crust as the weaker 'inherited' overlying mantle is thinned. When crustal separation occurs after 15 My extension, the $1300{ }^{\circ} \mathrm{C}$ isotherm is $40 \mathrm{~km}$ deep and remnants of the depleted mantle body can be found directly beneath the hyperextended crust of both margins, but neither depleted mantle, nor mafic crust is exhumed at the seafloor.

\subsubsection{Model 8: Moho $600{ }^{\circ} \mathrm{C}$}

When the geothermal gradient is is sufficiently high to produce a Moho temperature of $600{ }^{\circ} \mathrm{C}$ (Model 8 in Figures 6 and 7), the orogenic structures are immediately reactivated and continuously deformed. Two antithetic shear zones rooted in the crust-mantle boundary form at the center of the underplated area but no anastomosing shear zones form in the lower crust. As extension progresses, active upwelling of the asthenosphere begins in the center of the model. The suture zone is abandoned as it becomes offset from the active center. Until approximately $4 \mathrm{My}$ the depleted and overlying inherited mantle are simultaneously thinned by pure shear in the model center. From $\sim 4.5$ My onward, the inherited mantle becomes preferentially thinned compared to the depleted mantle. As a result, depleted mantle becomes juxtaposed against the base of the crust at both margins, as in Model 4. When

crustal separation occurs within the 'orogenic zone' at $13 \mathrm{My}$, both mafic lower crust and depleted mantle are exhumed to the seafloor. At this stage, the $1300{ }^{\circ} \mathrm{C}$ isotherm is at $40 \mathrm{~km}$ depth and both margins are $\sim 80 \mathrm{~km}$ wide. When we move the initial depleted mantle zone between 50 and $90 \mathrm{~km}$ instead of 60-100 km under the same geothermal gradient (Model 11 in Figure 8), crustal separation occurs outside the 'orogenic area'. In Model 11, crustal 
deformation is similar to crustal deformation in Model 8 until 4 My extension. In contrast, in the upper mantle, three pairs of shear zones form in Model 11 (one above each edge of the depleted mantle domain and one above its center), whereas only one shear zone is significantly active in the central part of the upper mantle in Model 8. In Model 11, the right-hand side pair of shear zones eventually localizes deformation, which results in crustal breakup to the right of the orogenic domain. Depleted mantle is juxtaposed beneath both margins with an asymmetrical distribution but is not exhumed to the seafloor (Figure 8).

\subsubsection{Model 9: Moho $500{ }^{\circ} \mathrm{C}$; $300{ }^{\circ} \mathrm{C}$ Hotter Underplating}

When the underplated area is $300{ }^{\circ} \mathrm{C}$ hotter than the encompassing lithosphere (Model 9 in Figures 6 and 7), the inherited structures are immediately reactivated and keep localizing deformation until the eventual crustal separation at 13.5 My. From 0.6 My onward, brittle deformation starts in the upper mantle, beneath the initial suture and faults. As a consequence, the upper mantle is efficiently thinned above the depleted mantle domain, and the latter becomes juxtaposed with the lower crust after 8 My extension. When the crust breaks-up, mafic underplating is exhumed to the seafloor but no depleted mantle. The final margins are about $100 \mathrm{~km}$ wide with the $1300{ }^{\circ} \mathrm{C}$ isotherm at a depth of $35 \mathrm{~km}$.

\subsubsection{Interpretation}

In the two coldest models with a thermally equilibrated lithosphere (Models 2 and 7), crustal separation occurs outside the underplated region despite the existence of weaknesses in the overlying upper crust (e.g. Figures 4 and 5). There is only minor deformation in the orogenic domain and both the crust and the lithosphere remain largely unthinned. In both cases, the zone of necking that will eventually become the locus of crustal separation develops on the right-hand side of the underplated region away from the orogenic structures. Rifting localizes further away from the orogenic area in the colder Model 2 than in Model 7. This suggests that the geothermal gradient controls the distance between the underplated region and the necking zone. This can be explained by the fact that, with the lowermost geothermal gradient (Moho $500{ }^{\circ} \mathrm{C}$ ), both the feldspar and the mantle (inherited or depleted) are relatively strong up to 25 and $50 \mathrm{~km}$ depth, respectively (Figure 3a), thus the orogenic 
region behaves almost as a single rigid block. In contrast, when the geothermal gradient is higher, the weakening of all rheological phases allow for some decoupling between the brittle upper crust and upper mantle (Figure 3b), allowing deformation localization at the edges of the strong heterogeneities. In the model with a higher geotherm, rifting localizes within the area containing the weaknesses (Model 8; Figures 6 and 7). This arises from the fact that, under the highest geothermal gradient of Model 8 (Moho temperature $600{ }^{\circ} \mathrm{C}$ ), feldspar has lost most of its strength at the depth of the 'mafic underplating' (i.e. between 22 and $30 \mathrm{~km}$ depth; Figure $3 \mathrm{c}$ ) and the rheological contrast between depleted and inherited mantle is limited to $60 \mathrm{~km}$ depth. As there is no significant rheological contrast between the orogenic area and adjacent lithosphere, the inherited weaknesses are the only significant strength heterogeneity, and thus control the location of crustal necking. Rifting processes are different in Model $9\left(+300{ }^{\circ} \mathrm{C}\right.$ thermal anomaly in the underplated zone), even if the final geometry is similar. Here, the local thermal anomaly results in a significant weaker rheology of the underplated region compared to adjacent lower crust (compare Figures 3a and d). As a result, extension focuses at this extreme lower crustal weakness and is then transmitted to the overlying crust and underlying mantle.

\section{Discussion}

\subsection{Thermally Equilibrated Underplating: a Barrier to Rifting?}

The results of Models 2, 3 and 7 (Figures 4 and 6) suggest that, within a cold to moderately hot lithosphere (Moho temperature $\leq 550{ }^{\circ} \mathrm{C}$ ), the existence of a mafic lower crust beneath a former orogenic area prevents significant deformation of pre-existing weaknesses during extension. Consequently, rifting and breakup localize away from the orogenic area, contrary to the prediction of the Wilson Cycle theory. The existence of mafic bodies within the lower crust may explain why both the Tethyan and southern North Atlantic rifts avoided the underplated Variscan and British Caledonian crust (Frizon de Lamotte et al., 2011; Chenin et al., 2015), while the northern North Atlantic rift reactivated the Caledonian Iapetus and Tornquist sutures in regions devoid of significant post-orogenic magmatism/underplating (Wilson (1966); Erratt et al. (1999); Figures 1a-c). 
The Variscan orogen of Western Europe is almost entirely surrounded by rifts, situated between the northward propagating Central Atlantic rift, the southward propagating northern North Atlantic rift, the eastward propagating Bay of Biscay and the Alpine Tethys rift system, the latter being largely parallel to the Variscan sutures of Western Europe. Therefore, inadequate rift orientation cannot be invoked to account for the lack of reactivation of the Variscan and British Caledonian orogenic structures. It seems that the different micro-plates of the Variscan collage were strongly welded during orogeny, forming a strong core that acted as a barrier to rift propagation. This hypothesis is consistent with the observation that both the development of the Porcupine Basin offshoreBritain and the Central Graben in the North Sea terminated close to the edges of the Variscan (underplated) domain (Figure 2c). Steckler and ten Brink (1986) invoked a comparable explanation to account for the dying of the north-northwestward propagating Gulf of Suez when it reached the hinge zone of the southeastern Mediterranean margin. According to them, the stronger rheology of the thinned continental crust or oceanic crust north of the hinge zone acted as a barrier to rift propagation. Consequently, deformation delocalized further east into the North-South-oriented Gulf of Aqaba and Dead Sea transform, which developed sub-parallel to the hinge zone.

Underplating may also explain why in the Basin and Range province of western United States present-day extension is essentially localized at the edges of the former orogenic domain, as highlighted by the distribution of seismic activity and GPS velocity measurements published by Bennett (2003). Indeed, like the Variscan orogen, the collapse of the former western US range was presumably accompanied with or followed by the emplacement of an up to $10 \mathrm{~km}$ thick mafic underplating of the continental crust, well-imaged on seismic sections (Jarchow et al., 1993; Rey, 1993).

The Bay of Biscay is a striking counterexample to this idea, since it opened within a region thought to be underplated. In this case, the major Biscay-North Pyrenean strike slip fault (Figures $1 \mathrm{~b}$ and c) that formed after the termination of the orogen may have been reactivated during the opening of the Bay of Biscay. Indeed, the Biscay-North Pyrenean fault formed during the phase of intense wrench faulting that occurred from latest Carboniferous to early Permian (Arthaud and Matte, 1977; Burg et al., 1994), that is during the early stages of the main mafic underplating episode that occurred in the Pyrenees (Petri et al., 2017). Since major strike-slip faults are pervasive 
structures that may crosscut the whole lithosphere (Vauchez et al., 1998) and the major Biscay-North Pyrenean fault was at play during part of the Permian magmatic event, it may not have been erased by the magmatic event and thus remained a weak zone within the underplated domain.

\subsection{Hot Underplating: A Preferred Location for Extension?}

When the geothermal gradient is high, mafic underplating may not be strong enough to act as a barrier to rifting. When magmatic intrusions are not thermally equilibrated, they may be even weaker than the surrounding material. In such cases, rifting may localize atop the underplated area, as illustrated in our Models 7 and 8 (Figures 6 and 7). These models can be compared with the South China Sea, which was affected by intense subduction- and orogen-related magmatism from the late Jurassic (Li et al., 2007) to late Cretaceous (Wintsch et al., 2011), prior to rift initiation in the late Cretaceous-early Paleocene (Holloway, 1982; Ru and Pigott, 1986; Lee and Lawver, 1994). Widespread granitoid intrusions can be found along the South China Sea margins and seismic imaging suggests that mafic crustal underplating exists beneath large parts of the South China Sea margins (Nissen et al., 1995; McIntosh et al., 2014). At least some of these underplated bodies are pre-rift (Nissen et al., 1995). Furthermore, the distributed rift-related extension in the South China Sea suggests that the geotherm was relatively high at the time of rifting (Moho temperature $>700{ }^{\circ} \mathrm{C}$; see Buck et al. (1999); McIntosh et al. (2014)).

\subsection{The Role of Depleted Mantle Heterogeneities}

Deeper than $\sim 50-60 \mathrm{~km}$ (depending on the geothermal gradient), the dry olivine rheology of the depleted mantle is comparable to that of 'inherited' mantle, here modeled as an average between dry and wet olivine. Therefore, the existence of zones of depleted mantle at a depth greater than $\sim 50-60 \mathrm{~km}$ may not affect the location of rifting. However, they may partially and/or temporarily protect the overlying region from stresses, which may influence the timing and duration of weak structure reactivation (compare Models 2 and 3). The slightly weaker rheology of inherited compared to depleted mantle results in a preferential thinning of the inherited mantle above and below the depleted 
mantle zone. As a consequence, the depleted mantle zone is progressively exhumed towards the surface and can become juxtaposed next to the hyperextended crust (Models 4 and 9) or even be exhumed to the seafloor (Model 8). This process may explain how remnants of deep and highly depleted mantle, interpreted as former upper part of the asthenospheric mantle that underwent the Variscan partial melting event, were exposed to the seafloor during the hyperextension stage of the Alpine Tethys rifting (McCarthy and Müntener, 2015; Picazo et al., 2016).

When located directly beneath the crust, as in magmatic arc settings (DeBari and Greene, 2011) or in the British Caledonides (Atherton and Ghani, 2002), regions of depleted mantle are significantly stronger than inherited mantle (Figures $3 \mathrm{a}-\mathrm{c}$ ). Therefore, they are likely to prevent reactivation of overlying weaknesses during extension (Model 6 in Figure 4). Such a zone of depleted mantle could explain the existence of unthinned continental crust at the Flemish Cap along the Newfoundland margin, where highly depleted arc-related mantle was reported at ODP Site 1277 (Müntener and Manatschal, 2006) and along the British Caledonides (the Rockall, Hatton and Porcupine banks), where the subcontinental lithospheric mantle has been depleted due to post-orogenic magmatism (Atherton and Ghani, 2002).

It is important to keep in mind that we modeled both the inherited and depleted mantle as two distinct homogeneous materials, assuming that inheritance is essentially erased at high temperatures (Yamasaki et al., 2006). However, the study by Toy et al. (2009) suggests that the existence of compositional heterogeneities such as pyroxenite dykes within the mantle may trigger the formation of localized shear zones during an episode of deformation.

\section{Conclusion}

The main conclusions of this study are: (1) Weaknesses inherited from an orogenic event may not localize deformation during a later extensional event if the orogen was massively underplated with gabbroic-pyroxenite melts and thermally equilibrated at the time of the onset of extension. This may explain why both the North Atlantic and Alpine Tethys rifts avoided the Variscan underplated lithosphere of Western Europe. (2) Similar to mafic underplating, shallow $(<50-60 \mathrm{~km})$ zones of depleted mantle are likely to prevent extension at overlying weaknesses in a thermally equilibrated lithosphere with a low to 
moderate geothermal gradient. Such zones of shallow depleted mantle, typically formed in magmatic arc settings, may account for the preservation of regions of unthinned crust during subsequent extension and rifting. (3) The existence of depleted mantle heterogeneities at a depth $>50-60 \mathrm{~km}$ beneath a former orogenic event does not impact the localization or duration of rifting. However, depleted mantle may be exhumed at the distal parts of the margins during a subsequent rifting event as a result of preferential thinning of the (weaker) overlying inherited mantle.

\section{A Additional models results}

Model 10 is similar to Reference Model 1, except that the suture zone stops at a depth of $22 \mathrm{~km}$. Model 10 is thus equivalent to Model 2 without underplating and depleted mantle. Model 11 is similar to Model 8, except that depleted mantle zone is initially located between 50 and $90 \mathrm{~km}$ depth instead of 60 and $100 \mathrm{~km}$.

\section{Acknowledgments}

This research was supported by ExxonMobil in the framework of the project CEIBA (Center of Excellence In Basin Analysis). Pauline Chenin was able to conduct the modeling experiments at UTIG - University of Texas thanks to the support from a Fulbright grant. We thank P. Rey and R. Holdsworth for their constructive reviews and comments. The data used to run the simulations are available in Table 1.

\section{References}

Amiguet, E., Van De Moortèle, B., Cordier, P., Hilairet, N., and Reynard, B. (2014). Deformation mechanisms and rheology of serpentines in experiments and in nature. Journal of Geophysical Research, 119:4640-4655.

Andersen, T. B. (1998). Extensional tectonics in the Caledonides of southern Norway, an overview. Tectonophysics, 285:333-351.

Anderson, D. L. (2006). Speculations on the nature and cause of mantle heterogeneity. Tectonophysics, 416(1-4):7-22.

Aradi, L., Hidas, K., Kovács, I., Tommasi, A., Klébesz, R., Garrido, C., and Szabó, C. (2017). Fluid-enhanced annealing in the subcontinental lithospheric mantle beneath the westernmost margin of the 


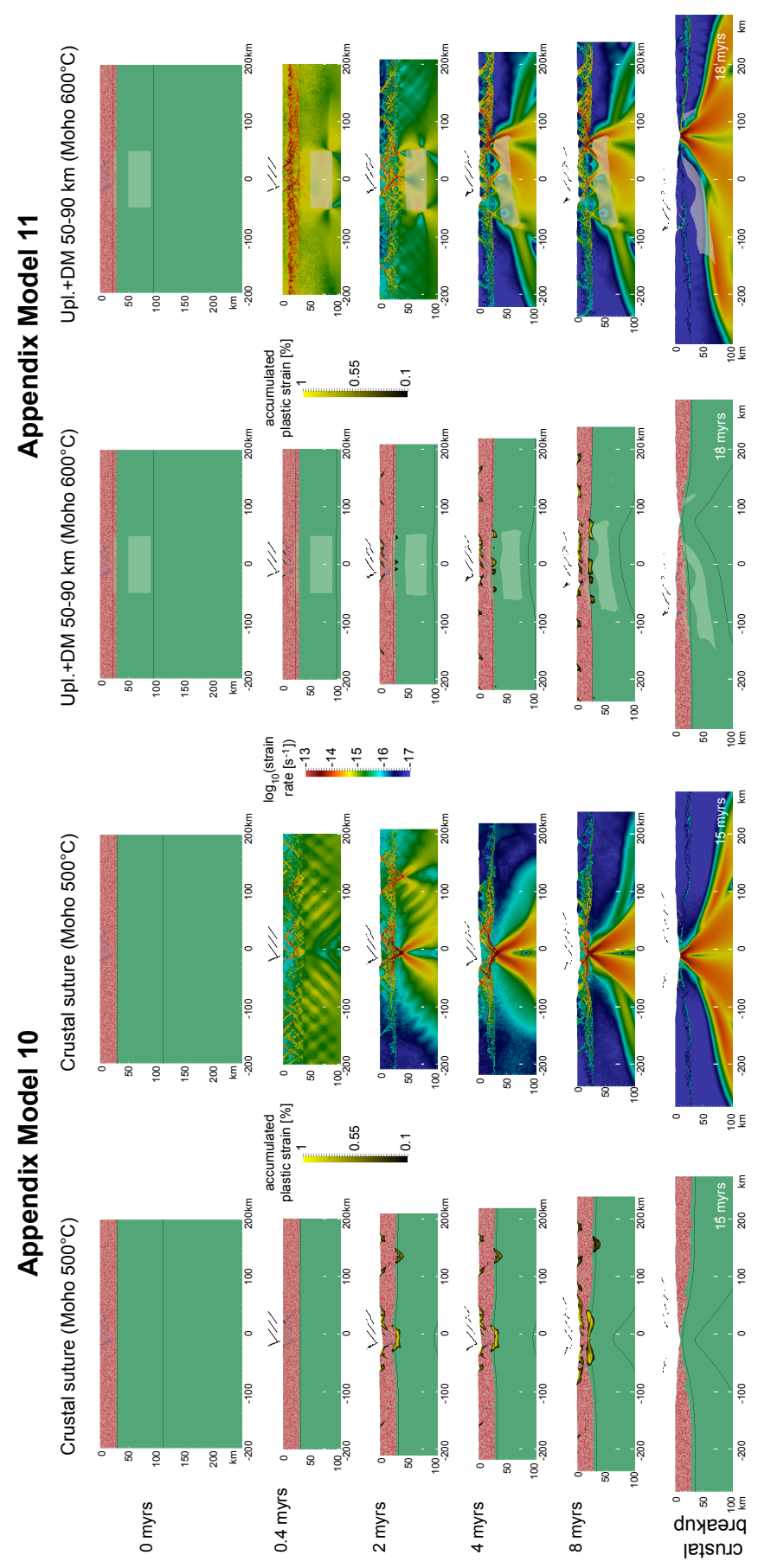

Figure 8: Phase and plastic strain $(>0.1 \%)$ distribution and strain rate evolution in Model 10 and 11; DM: depleted mantle; Upl.: mafic underplating of the crust. 
carpathian-pannonian extensional basin system. Tectonics, 36(12):2987-3011.

Arthaud, F. and Matte, P. (1977). Late Paleozoic strike-slip faulting in southern Europe and northern Africa: Result of a right-lateral shear zone between the Appalachians and the Urals. Geological Society of America Bulletin, 88(9):1305-1320.

Atherton, M. and Ghani, A. (2002). Slab breakoff: a model for Caledonian, Late Granite syn-collisional magmatism in the orthotectonic (metamorphic) zone of Scotland and Donegal, Ireland. Lithos, 62(3-4):65-85.

Audet, P. and Bürgmann, R. (2011). Dominant role of tectonic inheritance in supercontinent cycles. Nature Geoscience, 4(3):184-187.

Augier, R., Choulet, F., Faure, M., and Turrillot, P. (2015). A turning-point in the evolution of the Variscan orogen: the ca. 325 Ma regional partial-melting event of the coastal South Armorican domain (South Brittany and Vendee, France). Bulletin de la Société Géologique de France, 186(2-3):63-91.

Banda, E., Gallart, J., García-Dueñas, V., Dañobeitia, J., and Makris, J. (1993). Lateral variation of the crust in the Iberian peninsula: New evidence from the Betic Cordillera. Tectonophysics, 221(1):53-66.

Bennett, V. C. (2003). Compositional evolution of the mantle. Treatise on Geochemistry, 2:493-519.

Bois, C., Pinet, B., and Roure, F. (1989). Dating lower crustal features in France and adjacent areas from deep seismic profiles. In et al. Mereu, R. F., editor, Properties and processes of earth's lower crust, pages 17-31.

American Geophysical Union Geophysical Monograph 51.

Brune, S., Heine, C., Pérez-Gussinyé, M., and Sobolev, S. V. (2014). Rift migration explains continental margin asymmetry and crustal hyper-extension. Nature communications, 5:4014.

Buck, R., Lavier, L. L., and Poliakov, A. N. B. (1999). How to make a rift wide. Philosophical Transactions of the Royal Society A: Mathematical, Physical and Engineering Sciences, 357(1753):671-693.

Burg, J.-P., Van Den Dreissche, J., and Brun, J.-p. (1994). Syn- to post-thickening extension in the Variscan Belt of Western Europe: Modes and structural consequences. Géologie de la France, 3:33-51.

Buzzi, L. and Gaggero, L. (2008). Petrogenesis of post-orogenic Lower Permian andesites in southern Europe: insights into the collapse of the Variscan range. Geodinamica Acta, 21(5-6):273-290. 
Cappelletti, A., Tsikalas, F., Nestola, Y., Cavozzi, C., Argnani, A., Meda, M., and Salvi, F. (2013). Impact of lithospheric heterogeneities on continental rifting evolution: Constraints from analogue modelling on South Atlantic margins. Tectonophysics, 608(0316):30-50.

Čermák, V. and Bodri, L. (1986). Two-dimensional temperature modelling along five East-European geotraverses. Journal of Geodynamics, $5(2): 133-163$.

Chenin, P. and Beaumont, C. (2013). Influence of offset weak zones on the development of rift basins: Activation and abandonment during continental extension and breakup. Journal of Geophysical Research, 118(4):1698-1720.

Chenin, P., Manatschal, G., Lavier, L. L., and Erratt, D. (2015). Assessing the impact of orogenic inheritance on the architecture, timing and magmatic budget of the North Atlantic rift system: a mapping approach. Journal of the Geological Society, 172(6):711-720.

Chenin, P., Manatschal, G., Picazo, S., Müntener, O., Karner, G. D., Johnson, C., and Ulrich, M. (2017). Influence of the architecture of magma-poor hyperextended rifted margins on orogens produced by the closure of narrow versus wide oceans. Geosphere, 13(2):1-18.

Costa, S. and Rey, P. (1995). Lower crustal rejuvenation and growth during post-thickening collapse: Insights from a crustal cross section through a Variscan metamorphic core complex. Geology.

Cundall, P. A. (1989). Numerical experiments on localization in frictional materials. Ingenieur-Archiv, 59(2):148-159.

DeBari, S. M. and Greene, A. R. (2011). Vertical stratification of composition, density, and inferred magmatic processes in exposed arc crustal sections. In Arc-continent collision, pages 121-144. Springer.

Dewey, J. F. (1988). Extensional collapse of orogens. Tectonics, $7(6): 1123-1139$.

Dunbar, J. A. and Sawyer, D. S. (1989). How preexisting weaknesses control the style of continental breakup. Journal of Geophysical Research, 94(B6):7278-7292.

Duretz, T., Petri, B., Mohn, G., Schmalholz, S. M., Schenker, F. L., and Müntener, O. (2016). The importance of structural softening for the evolution and architecture of passive margins. Scientific reports, 6:38704.

Erratt, D., Thomas, G. M., and Wall, G. R. T. (1999). The evolution of the Central North Sea Rift. In Fleet, A. J. and Boldy, S. A. R., editors, Petroleum Geology of Northwest Europe: Proceedings of the 5th Conference, pages $63-82$. The Geological Society, London. 
Fossen, H., Gabrielsen, R. H., Faleide, J. I., and Hurich, C. A. (2014). Crustal stretching in the Scandinavian Caledonides as revealed by deep seismic data. Geology, 42(9):791-794.

Fountain, D. M. (1976). The Ivrea-Verbano and Strona-Ceneri Zones, Northern Italy: A cross-section of the continental crust-New evidence from seismic velocities of rock samples. Tectonophysics, 33(1-2):145-165.

Frizon de Lamotte, D., Raulin, C., Mouchot, N., Wrobel-Daveau, J.-C., Blanpied, C., and Ringenbach, J.-C. (2011). The southernmost margin of the Tethys realm during the Mesozoic and Cenozoic: Initial geometry and timing of the inversion processes. Tectonics, 30(3):1-22.

Hall, R. (1976). Ophiolite emplacement and the evolution of the Taurus suture zone, southeastern Turkey. Geological Society of America Bulletin, 87(7):1078-1088.

Haxby, W. F., Melkonian, A. K., Coplan, J., Chan, S. M., and Ryan, W. B. F. (2010). GeoMapApp freeware software, v. 2.3. LamontDoherty Earth Observatory, Palisades, NY.

Haynes, S. J. and McQuillan, H. (1974). Evolution of the Zagros Suture Zone, Southern Iran. Geological Society of America Bulletin, 85(5):739-744.

Hirth, G. and Kohlstedt, D. L. (1996). Water in the oceanic upper mantle: implications for rheology, melt extraction and the evolution of the lithosphere. Earth and Planetary Science Letters, 144(1-2):93-108.

Holdsworth, R. E., Butler, C. A., and Roberts, A. M. (1997). The recognition of reactivation during continental deformation. Journal of the Geological Society, 154(1):73-78.

Holloway, N. H. (1982). North Palawan Block, Philippines; its relation to Asian mainland and role in evolution of South China Sea. AAPG Bulletin, 66(9):1355-1383.

Huismans, R. and Beaumont, C. (2011). Depth-dependent extension, two-stage breakup and cratonic underplating at rifted margins. Nature, 473(7345):74-78.

Huismans, R. S. and Beaumont, C. (2007). Roles of lithospheric strain softening and heterogeneity in determining the geometry of rifts and continental margins. In Karner, G. D., Manatschal, G., and Pinhiero, L. M., editors, Imaging, Mapping and Modelling Continental Lithosphere Extension and Breakup, pages 107-134. Geological Society, London, Special Publications, 282.

Huismans, R. S., Podladchikov, Y. Y., and Cloetingh, S. A. P. L. (2001). Transition from passive to active rifting: Relative importance of asthenospheric doming and passive extension of the lithosphere. Journal of Geophysical Research, 106(B6):11,271-11,291. 
Jammes, S. and Lavier, L. L. (2016). The effect of bimineralic composition on extensional processes at lithospheric scale. Geochemistry, Geophysics, Geosystems, 17(8):3375-3392.

Jammes, S., Lavier, L. L., and Reber, J. E. (2015). Localization and delocalization of deformation in a bimineralic material. Journal of Geophysical Research, 120(5):3649-3663.

Jarchow, C. M., Thompson, G. A., Catchings, R. D., and Mooney, W. D. (1993). Seismic evidence for active magmatic underplating beneath the Basin and Range Province, western United States. Journal of Geophysical Research, 98(B12):22095.

Jaupart, C. and Mareschal, J. C. (2007). Heat flow and thermal structure of the lithosphere. Treatise on Geophysics, 6:217-251.

Keller, T. and Katz, R. F. (2016). The role of volatiles in reactive melt transport in the asthenosphere. Journal of Petrology, 57(6):1073-1108.

Keller, T., May, D. A., and Kaus, B. J. (2013). Numerical modelling of magma dynamics coupled to tectonic deformation of lithosphere and crust. Geophysical Journal International, 195(3):1406-1442.

Krabbendam, M. (2001). When the Wilson Cycle breaks down: how orogens can produce strong lithosphere and inhibit their future reworking. Geological Society, London, Special Publications, 184(1):57-75.

Lavier, L. L. (2002). Half graben versus large-offset low-angle normal fault: Importance of keeping cool during normal faulting. Journal of Geophysical Research, 107(B6):1-16.

Lavier, L. L., Buck, W. R., and Poliakov, A. N. B. (2000). Factors controlling normal fault offset in an ideal brittle layer. Journal of Geophysical Research, 105(B10):23431-23442.

Lavier, L. L. and Manatschal, G. (2006). A mechanism to thin the continental lithosphere at magma-poor margins. Nature, 440(7082):324-328.

Lee, T.-Y. and Lawver, L. A. (1994). Cenozoic plate reconstruction of the South China Sea region. Tectonophysics, 235(1-2):149-180.

Li, X. H., Li, Z. X., Li, W. X., Liu, Y., Yuan, C., Wei, G., and Qi, C. (2007). $\mathrm{U}-\mathrm{Pb}$ zircon, geochemical and $\mathrm{Sr}-\mathrm{Nd}-\mathrm{Hf}$ isotopic constraints on age and origin of Jurassic I- and A-type granites from central Guangdong, SE China: A major igneous event in response to foundering of a subducted flat-slab? Lithos, 96(1-2):186-204.

Manatschal, G., Lavier, L., and Chenin, P. (2015). The role of inheritance in structuring hyperextended rift systems: Some considerations based on observations and numerical modeling. Gondwana Research, 27(1):140-164. 
McCarthy, A. and Müntener, O. (2015). Ancient depletion and mantle heterogeneity: Revisiting the Permian-Jurassic paradox of Alpine peridotites. Geology, 43(3):255-258.

McIntosh, K., Lavier, L., van Avendonk, H., Lester, R., Eakin, D., and Liu, C.-S. (2014). Crustal structure and inferred rifting processes in the northeast South China Sea. Marine and Petroleum Geology, 58:612-626.

Meissner, R. (1999). Terrane accumulation and collapse in central Europe: seismic and rheological constraints. Tectonophysics, 305(1-3):93-107.

Müntener, O., Hermann, R. G., and Trommsdorff, V. (2000). Cooling History and Exhumation of Lower- Crustal Granulite and Upper Mantle (Malenco, Eastern Central Alps). Journal of Petrology, 41(2):175-200.

Müntener, O. and Manatschal, G. (2006). High degrees of melt extraction recorded by spinel harzburgite of the Newfoundland margin: The role of inheritance and consequences for the evolution of the southern North Atlantic. Earth and Planetary Science Letters, 252:437-452.

Müntener, O., Pettke, T., Desmurs, L., Meier, M., and Schaltegger, U. (2004). Refertilization of mantle peridotite in embryonic ocean basins: trace element and $\mathrm{Nd}$ isotopic evidence and implications for crust-mantle relationships. Earth and Planetary Science Letters, 221:293-308.

Nagel, T. J. and Buck, W. R. (2007). Control of rheological stratification on rifting geometry: a symmetric model resolving the upper plate paradox. International Journal of Earth Sciences, 96(6):1047-1057.

Neilson, J., Kokelaar, B., and Crowley, Q. (2009). Timing, relations and cause of plutonic and volcanic activity of the Siluro-Devonian post-collision magmatic episode in the Grampian Terrane, Scotland. Journal of the Geological Society, 166(3):545-561.

Nissen, S. S., Hayes, D. E., Buhl, P., Diebold, J., Bochu, Y., Zeng, W., and Chen, Y. (1995). Deep penetration seismic soundings across the northern margin of the South China Sea. Journal of Geophysical Research, 100(B11):22,407-22,433.

Petri, B., Duretz, T., Mohn, G., Schmalholz, S. M., Karner, G. D., and Müntener, O. (2019). Thinning mechanisms of heterogeneous continental lithosphere. Earth and Planetary Science Letters, 512:147-162.

Petri, B., Mohn, G., Skrzypek, E., Mateeva, T., Galster, F., and Manatschal, G. (2017). U-pb geochronology of the sondalo gabbroic complex (central alps) and its position within the permian post-variscan extension. International Journal of Earth Sciences, 106(8):2873-2893. 
Picazo, S., Müntener, O., Manatschal, G., Bauville, A., Karner, G. D., and Johnson, C. (2016). Mapping the nature of mantle domains in Western and Central Europe based on clinopyroxene and spinel chemistry: evidence for mantle modification during an extensional cycle. Lithos.

Poliakov, A., Podladchikov, Y., and Talbot, C. (1993). Initiation of salt diapirs with frictional overburdens: numerical experiments. Tectonophysics, 228(3-4):199-210.

Rampone, E., Hofmann, A. W., Piccardo, G. B., Vannucci, R., Bottazzi, P., and Ottolini, L. (1996). Trace element and isotope geochemistry of depleted peridotites from an N-MORB type ophiolite (Internal Liguride, N. Italy). Contributions to Mineralogy and Petrology, 123(1):61-76.

Rey, P. (1993). Seismic and tectono-metamorphic characters of the lower continental crust in Phanerozoic areas: a consequence of post-thickening extension. Tectonics, 12(2):580-590.

Rey, P., Vanderhaeghe, O., and Teyssier, C. (2001). Gravitational collapse of the continental crust: Definition, regimes and modes. Tectonophysics, 342(3-4):435-449.

Rosas, F. M., Marques, F. O., Ballèvre, M., and Tassinari, C. (2008). Geodynamic evolution of the SW Variscides: Orogenic collapse shown by new tectonometamorphic and isotopic data from western Ossa-Morena Zone, SW Iberia. Tectonics, 27(6):n/a-n/a.

Rossi, P., Cocherie, A., and Fanning, C. M. (2015). Evidence in Variscan Corsica of a brief and voluminous Late Carboniferous to Early Permian volcanic-plutonic event contemporaneous with a high-temperature/low-pressure metamorphic peak in the lower crust. Bulletin de la Société Géologique de France, 186(2-3):171-192.

Ru, K. and Pigott, J. D. (1986). Episodic rifting and subsidence in the South China Sea. AAPG Bulletin, 70(9):1136-1155.

Schaltegger, U. and Corfu, F. (1995). Late Variscan 'Basin and Range' magmatism and tectonics in the Central Alps: evidence from U-Pb geochronology. Geodinamica Acta, 8(2):82-98.

Schuster, R. and Stüwe, K. (2008). Permian metamorphic event in the Alps. Geology, 36(8):603-606.

Simancas, J. F., Tahiri, A., Azor, A., Lodeiro, F. G., Martínez-Poyatos, D. J., and El Hadi, H. (2005). The tectonic frame of the Variscan Alleghanian orogen in Southern Europe and Northern Africa. Tectonophysics, 398:181-198. 
Steckler, M. S. and ten Brink, U. S. (1986). Lithospheric strength variations as a control on new plate boundaries: examples from the northern Red Sea region. Earth and Planetary Science Letters, 79:120-132.

Svartman Dias, A. E., Lavier, L. L., and Hayman, N. W. (2015). Conjugate rifted margins width and asymmetry: The interplay between lithospheric strength and thermomechanical processes. Journal of Geophysical Research: Solid Earth, 120(12):8672-8700.

Sykes, L. R. (1978). Intraplate Seismicity, Reactivation of Preexisting Zones of Weakness, Alkaline Magmatism, and Other Tectonism Postdating Continental Fragmentation. Reviews of Geophysics, 16(4):621-688.

Tan, E., Lavier, L. L., Van Avendonk, H. J. A., and Heuret, A. (2012). The role of frictional strength on plate coupling at the subduction interface. Geochemistry, Geophysics, Geosystems, 13(10):n/a-n/a.

Timmerman, M. J., Heeremans, M., Kirstein, L. A., Larsen, B. T., Spencer-Dunworth, E.-A., and Sundvoll, B. (2009). Linking changes in tectonic style with magmatism in northern Europe during the late Carboniferous to latest Permian. Tectonophysics, 473(3-4):375-390.

Toy, V. G., Newman, J., Lamb, W., and Tikoff, B. (2009). The role of pyroxenites in formation of shear instabilities in the mantle: evidence from an ultramafic ultramylonite, twin sisters massif, washington. Journal of Petrology, 51(1-2):55-80.

Vauchez, A., Tommasi, A., and Barruol, G. (1998). Rheological heterogeneity, mechanical anisotropy and deformation of the continental lithosphere. Tectonophysics, 296(1-2):61-86.

Vavra, G., Gebauer, D., Schmid, R., and Compston, W. (1996). Multiple zircon growth and recrystallization during polyphase Late Carboniferous to Triassic metamorphism in granulites of the Ivrea Zone (Southern Alps): an ion microprobe (SHRIMP) study. Contributions to Mineralogy and Petrology, 122(4):337-358.

Williamson, J. P., Pharaoh, T. C., Banka, D., Thybo, H., Laigle, M., and Lee, M. K. (2002). Potential field modelling of the Baltica - Avalonia (Thor Tornquist) suture beneath the southern North Sea. Tectonophysics, 360:47-60.

Wilson, J. T. (1966). Did the Atlantic close and then re-open? Nature, 211:676-681.

Wintsch, R. P., Yang, H. J., Li, X. H., and Tung, K. A. (2011). Geochronologic evidence for a cold arc-continent collision: The Taiwan orogeny. Lithos, 125(1-2):236-248. 
Yamasaki, T., O'Reilly, B., and Readman, P. (2006). A rheological weak zone intensified by post-rift thermal relaxation as a possible origin of simple shear deformation associated with reactivation of rifting. Earth and Planetary Science Letters, 248(1-2):119-131.

Ziegler, P. A. and Dèzes, P. (2006). Crustal Evolution of Western and Central Europe. In Gee, D. G. and Stephenson, R. A., editors, European Lithosphere Dynamics, pages 43-56. Geological Society, London, Memoir 32. 